\title{
Abortion by telemedicine in Northern Ireland: patient and professional rights across borders
}

\author{
TAMARA HERVEY
}

University of Sheffield

and

SALLY SHELDON

University of Kent*

\begin{abstract}
The uneasy legal and political settlement regarding abortion in Northern Ireland has long relied on the outsourcing of aspects of reproductive health care. While local health services offer only highly restricted access to termination procedures, women travel to access abortion services elsewhere. However, technological changes, in particular the development of abortifacient medicines, are revolutionising this aspect of reproductive healthcare. Rather than women having to travel to a service, today that service can travel to women through the postal supply of abortion pills, sourced via the internet. While online supply of pharmaceuticals can pose potential public health risks, at least two groups offer safe and effective telemedical services to women in Northern Ireland. Women on Web and Women Help Women each supply abortion pills, under prescription from a doctor based in another country, to women who wish to end a pregnancy of nine weeks or less. Here, we consider the extent to which the telemedical abortion services that they offer are protected by transnational law, in particular, EU provisions on cross-border services. This offers new and hitherto unexplored lines of legal argument (including defences against criminal prosecution and challenges to a state's attempts to restrict the flow of services). Through claiming the autonomy-based legal relationships implicit in transnational law and the power that flows therefrom, we suggest, women may challenge regulatory arrangements which seek to limit their reproductive rights.
\end{abstract}

\section{Introduction}

Tn April 2016, the first woman in at least a decade was convicted of illegal abortion in Northern Ireland. ${ }^{1}$ Finding herself pregnant at 19 years of age and unable to raise the money to travel to England for a legal termination, she had taken abortion pills sourced

* We are grateful to the SURE student intern scheme at the University of Sheffield; to Laura Robinson, our SURE student, for her enthusiastic and persistent contributions; to the Arts and Humanities Research Council (AHRC) for funding Sheldon's research into the regulation of abortion pills (AH/L006537/1; <www.kent.ac.uk/law/mabal/index.html>); and to the following for constructive and insightful feedback on earlier drafts of this paper or parts thereof: Professor Kenneth Armstrong; Professor Marie Fox; Dr Goretti Horgan; Dr Sorcha Macleod; Dr Bríd Ní Ghráinne; Professor Steven Peers; Professor Sol Picciotto; Stefanie Pletz; Flora Renz; Dr Oisin Suttle; and an anonymous reviewer.

1 Henry McDonald, 'Northern Irish Woman Given Suspended Sentence over Self-induced Abortion’ The Guardian (4 April 2016) <www.theguardian.com/uk-news/2016/apr/04/northern-irish-woman-suspended-sentence-selfinduced-abortion>. A freedom of information request submitted by Dr Goretti Horgan found that no woman had been convicted under s 58, Offences Against the Person Act 1861, between 1 April 2007 and 31 March 2015 (on file with the authors). 
online. Her flatmates reported her to the police. In sentencing her, the judge is reported to have complained that he was asked to enforce a statute that was 150 years old. ${ }^{2}$ While the offence of 'unlawful procurement of miscarriage' under that mid-Victorian law carries a maximum penalty of life imprisonment, he imposed a far lower sentence: three months' imprisonment, suspended for two years. In the view of the Northern Ireland Justice Minister, this was 'justice . . . tempered with considerable mercy'. ${ }^{3}$ Another woman is currently facing charges for having procured abortion pills to allow her teenage daughter to end an unwanted pregnancy. ${ }^{4} \mathrm{~A}$ third prosecution, of a woman and her partner for allegedly using medical abortion pills to self-induce an abortion, was recently dropped by the prosecution in the light of expert medical evidence of the risk to the woman's mental health, and potentially her suicide, were the case to be publicised. The couple accepted formal cautions. ${ }^{5}$

These women faced one of the most restrictive abortion laws in Europe and one which has been repeatedly condemned for its gender-discriminatory impact in denying women treatment that only they need; 6 for its negative effect on women's health; ${ }^{7}$ for its breach of women's rights to privacy ${ }^{8}$ and to be free from inhuman and degrading treatment; ${ }^{9}$ and for its lack of clarity. ${ }^{10}$ Criminal justice and health and social care are both devolved matters. However, notwithstanding such stringent criticism, the Northern Ireland Assembly has thus far resisted calls for change, recently voting against reform to permit abortion in the presence of a fatal fetal anomaly. ${ }^{11}$ In refusing even this very modest liberalisation of the law, Stormont appears out of line not just with the requirements of human rights law, but

2 McDonald (n 1).

3 David Ford, interviewed for the Roger Phillips show, BBC Radio Merseyside, 6 April 2016.

4 Henry McDonald, 'Pro-choice Activists Picket Derry Police Station over Mother's Abortion Trial' The Guardian (15 July 2015) <www.theguardian.com/uk-news/2015/jul/15/pro-abortion-campaigners-picketderry-police-station-mother-prosecution $>$. A judicial review of the decision to prosecute is imminent at the time of writing.

5 Alan Irwin, 'Man and Woman Cautioned over "Abortion Pills" in Northern Ireland' Belfast Telegraph (19 January 2017) <www.belfasttelegraph.co.uk/news/northern-ireland/man-and-woman-cautioned-overabortion-pills-in-northern-ireland-35378188.html>.

6 Amnesty International UK, The Criminal Law on Abortion: Lethal Foetal Abnormality and Sexual Crime (Amnesty 2015). For discussion of repeated condemnations of Northern Ireland's abortion law by the Committee on the Elimination of Discrimination against Women, see Catherine O'Rourke, 'Advocating Abortion Rights in Northern Ireland: Local and Global Tensions' (2016) 25(6) Social and Legal Studies 716.

7 UN Human Rights Committee, 'Concluding Observations on the Seventh Periodic Report of the United Kingdom of Great Britain and Northern Ireland' (24 July 2015) $<$ http://tbinternet.ohchr.org/_layouts/treatybodyexternal/Download.aspx?symbolno=CCPR $\% 2 \mathrm{fC} \% 2 \mathrm{fGB}$ $\mathrm{R} \% 2 \mathrm{fCO} \% 2 \mathrm{f} 7 \&$ Lang=en> para 17.

8 Northern Ireland Human Rights Commission's Application [2015] NIQB 96.

9 UN Human Rights Committee, Amanda Jane Mellet v Ireland, 9 June 2016, UN Doc CCPR/C/ 116/D/2324/2013.

10 Committee on the Administration of Justice, Submission to the Department of Justice in Response to their Consultation on the Criminal Law on Abortion: Lethal Foetal Abnormality and Sexual Crime (December 2014) <www.caj.org.uk/files/2014/12/02/S439_Submission_to_DoJ_consultation_on_the_criminal_law_on_abor tion.pdf $>$.

11 Anon, 'Stormont Rejects Abortion for Fatal Foetal Abnormality Cases' RTE News (11 February 2016) <www.rte.ie/news/2016/0211/767072-abortion-stormont $>$. This ignored the recommendation of the Department of Justice, The Criminal Law on Abortion: Lethal Fetal Abnormality and Sexual Crime Response to the Consultation and Policy Proposals (April 2015) para 8.29. For further discussion, see Fiona de Londras, 'Fatal Foetal Abnormality, Irish Constitutional Law and Mellet v Ireland (2016) Medical Law Review (online first, doi:10.1093/medlaw/fww040); and Aisling McMahon and Bríd Ní Ghráinne, 'Abortion, Ireland and International Law' paper presented at the American Society of International Law Annual Meeting, November 2016. 
also with local public opinion. ${ }^{12}$ Moreover, in denying women in Northern Ireland the access to abortion enjoyed elsewhere in the UK, the law is also in clear contravention of the UK government's published views on the need to make safe, legal abortion available as a basic human right. ${ }^{13}$ This endorsement of abortion rights for women in developing countries contrasts markedly with the refusal to ensure the recognition of such rights for its own citizens in a devolved region of the UK. ${ }^{14}$

While previous critiques of Northern Irish abortion law have tended to focus on these important human rights arguments, we explore a further significant issue that has been ignored to date: how restrictions on women's home use of abortion pills within Northern Ireland fit with transnational trade law. Rather than attempting to discuss the full range of relevant regulatory frameworks at stake here (including the law of the World Trade Organization and various bilateral or multilateral free-trade agreements), we focus on obligations within EU law. At the time of writing, it remains unclear what the postBrexit arrangements on trade in medical services will be. ${ }^{15} \mathrm{It}$ is possible that the UK will enter into some form of bespoke bilateral trade agreement with the EU, for instance, modelled on the EU-Canada Comprehensive Economic and Trade Agreement (CETA) ${ }^{16}$ or the Transatlantic Trade and Investment Partnership (TTIP). ${ }^{17}$ However, in the absence of relevant EU law post-Brexit, where other international trade instruments apply to

12 Amnesty International, Abortion Research (October 2016) <www.amnesty.org.uk/sites/ default/files/millward_brown_report_of_public_opinion_research_oct_2016.pdf $>$; LucidTalk, Tracker Poll (Northern Ireland) (December 2016) <https://lucidtalk.co.uk/images/News/LTDec16TrackerPollResultsGeneralRpt.pdf $>$. This most recent poll showed $55.8 \%$ in favour of having Northern Ireland abortion laws which were 'totally compatible' with those in the rest of the UK, $18.6 \%$ in favour of a more limited liberalisation, $16.3 \%$ in favour of abortion only when the life of the mother is at extreme risk and only $7 \%$ against abortion in all circumstances.

13 Department for International Development (DFID), DFID's Policy Position on Safe and Unsafe Abortion (DFID $2009)<$ www.pacifichealthsummit.org/downloads/MNH/International $\% 20$ Guidelines $\% 20$ and $\% 20$ Policy $\% 20$ Resources/DFID $\%$ E2 $\% 80 \% 99 \mathrm{~s} \% 20$ policy $\% 20$ position $\% 20$ on $\% 20$ safe $\% 20$ and $\% 20$ unsafe $\% 20$ abortion.PDF> 1,5 .

14 Goretti Horgan and Julia S O'Connor, 'Abortion and Citizenship Rights in a Devolved Region of the UK' (2014) 13(1) Social Policy and Society 39.

15 Prime Minister Theresa May has clarified - <www.independent.co.uk/news/uk/home-news/full-text-theresamay-brexit-speech-global-britain-eu-european-union-latest-a7531361.html> - that the UK will not seek to remain in the single market, so we can almost certainly rule out the European Economic Area (EEA) Agreement, which applies EU law of the 'single market' to European Free Trade Association states. This includes free movement of goods and services, including medical services, see Art 1(2), 8 and 36 EEA, OJ $1994 \mathrm{~L} 1 / 3$.

16 The CETA was signed on 30 October 2016. Most of the CETA will apply provisionally once the European Parliament consents and a decision on provisional application is formally adopted by the European Council. The CETA will come into force only if adopted by the EU Council with the consent of the European Parliament, and by every EU member state in accordance with its national constitutional arrangements. The EU has entered a reservation under CETA for 'Retail sales of pharmaceutical . . goods, other services provided by pharmacists', see Consolidated CETA text, 1298: <http://trade.ec.europa.eu/doclib/ docs/2014/september/tradoc_152806.pdf $>$. The reservation states that for all member states of the EU with the exception of Belgium, Bulgaria, Estonia and Ireland, mail order is only possible from member states of the EEA, thus establishment in any of these countries is required for the retail of pharmaceuticals and specific medical goods to the general public in the EU. The implication is that providers of medicines by remote means, such as mail order, could not establish in Canada and sell in the EU. The reservation goes on to state that in Bulgaria, Germany, Estonia and Ireland the mail order of pharmaceuticals/prescription-only pharmaceuticals is prohibited. However, such a blanket prohibition has been repeatedly challenged for being in breach of EU law, especially by the repeat litigant internet pharmacy DocMorris, most recently in Case C-148/15 Deutsche Parkinson Vereinigung 19 October 2016 EU:C:2016:776.

17 The TTIP is now 'on ice' following the election of Donald Trump to the US Presidency. Application to medical services is one of its (many) controversial aspects, see Ferdi de Ville and Gabriel Siles-Brugge, The Truth about the Transatlantic Trade and Investment Partnership (Polity 2016). 
cross-border medical services, some of the opportunities for legal and political contestation discussed in this paper will continue to apply. Further, regardless of the relevance of EU law to Northern Ireland post-Brexit, our legal analysis applies both to any prosecutions brought in circumstances where women have used abortion pills preBrexit and also to women in other EU countries - such as the Republic of Ireland, Poland and Italy - who are similarly avoiding the strictures of highly restrictive abortion laws by accessing abortion pills online. ${ }^{18}$ While we have chosen not to sacrifice necessary depth in our discussion of EU law by also investigating this far broader range of regulation here, the general thrust of our analysis may also apply elsewhere in the world, where other kinds of transnational regulation cover trade in medical services.

As we will see, EU law protects patient autonomy and choice, professionals' access to extra-jurisdictional patients, and non-discrimination within the EU's human rights framework. Further, for the immediate future, the UK will remain a party to the European Convention on Human Rights (ECHR). ${ }^{19}$ This means that under any bilateral or multilateral trade agreement with the EU and/or other countries the UK will remain bound to respect the rights contained in that Convention, as well as the general common law legal principle of non-discrimination, in the sense of treating like situations or persons alike, in the interpretation and application of international trade law within its borders. General conclusions that we draw from how EU law interacts with human rights law, through obligations of consistent interpretation of national laws, thus apply also to transnational trade law in general and to any future arrangements in the UK post-Brexit.

Issues of free movement come into particularly sharp focus in a context where safe and effective abortion pills can be obtained by women in the EU on prescription issued by an appropriately accredited doctor based in another country. Access to these pills can play a significant role in promoting women's reproductive health and autonomy, while simultaneously - and highly controversially - allowing women to escape domestic criminal prohibitions against abortion that reflect religious and moral concerns for the protection of fetal life. The detailed, technical legal analysis below thus also speaks to far broader legal and policy debates on the meaning and scope of 'autonomy' in the context of EU citizenship rights, the extent to which those rights and autonomy are inevitably constrained within the logic of the market, and hence questions of the scope or reach of

18 See, generally, Sally Sheldon, 'How Can a State Control Swallowing? The Home Use of Abortion Pills in Ireland' (2016) Reproductive Health Matters online first: <http://dx.doi.org/10.1016/j.rhm.2016.10.002>; Stephanie Kirchgaessner, Pamela Duncan, Alberto Nardelli and Delphine Robineau, 'Seven in 10 Italian Gynaecologists Refuse to Carry out Abortions' The Guardian (11 March 2016) <www.theguardian.com/world/2016/mar/11/italian-gynaecologists-refuse-abortions-miscarriages>; Radhika Sanghani, “'Abortion Drone” to Drop DIY Drugs over Poland to Women' The Telegraph (22 June 2015) <www.telegraph.co.uk/women/womens-life/11691081/Abortion-drone-to-drop-DIY-drugs-overPoland-to-women.html>. An attempt to extend our arguments to the Republic of Ireland would face the additional hurdle of the Protocol attached to the Maastricht Treaty, which states that nothing in EU law shall 'affect the application in Ireland of Article 40.3.3 of the Constitution of Ireland'.

19 It should be noted, however, that the Prime Minister has repeatedly suggested that the UK should leave the ECHR, although she has recently announced that such plans are 'on hold' until at least 2020: Christopher Hope, 'Theresa May to Fight 2020 Election on Plans to take Britain out of European Convention on Human Rights after Brexit is Completed' The Telegraph (28 December 2016) <www.telegraph.co.uk/news/2016/12/28/theresa-may-fight-2020-election-plans-take-britain-european>. 
EU law, including into sensitive moral matters; ${ }^{20}$ and whether the laws and the policies of the EU are good for women. ${ }^{21}$

Before considering the relevant EU law, we provide some more detail regarding, first, Northern Ireland's abortion law and, second, how women within the jurisdiction are accessing abortion pills via telemedicine. These details, particularly concerning the groups who supply the pills and the safety of the service which they offer, are important when it comes to distinguishing the application of EU law in this instance from a situation where unscrupulous, unqualified providers sell (potentially inauthentic) medicines directly via the internet, without the involvement of any medical professional. Given secrecy regarding the use of abortion pills in Northern Ireland, in these first parts of the paper, we rely in part on information gathered in a series of fact-finding interviews conducted with a range of key actors, including: government officials; family-planning service providers; support groups; activists; and two not-for-profit groups - Women on Web (WoW) and Women Help Women (WHW) - which arrange the supply of abortion pills to women in Northern Ireland. ${ }^{22}$ We then consider the relevance of EU law to these telemedical abortion services, considering both doctors' rights to provide services across borders and patients' rights to receive them.

\section{Abortion law in Northern Ireland}

Criminal prohibitions against abortion in Northern Ireland (as in England and Wales) are laid down in the Offences Against the Person Act 1861, ss 58-9, a statute passed at the midpoint of the reign of Queen Victoria, 23 a time that 'in matters sexual' was 'almost unimaginably different from ours'.24

58 Every woman being with child, who, with intent to procure her own miscarriage shall unlawfully administer to herself any poison or other noxious thing, or shall unlawfully use any instrument or other means whatsoever with the like intent, and whosoever, with intent to procure the miscarriage of any woman, whether she be or be not with child, shall unlawfully administer to her or cause to be taken by her any poison or other noxious thing, or shall unlawfully use any instrument or other means whatsoever with the like

20 For an early discussion, see Michelle Everson, 'The Legacy of the Market Citizen' in Gillian More and Jo Shaw (eds), New Legal Dynamics of European Union (Clarendon 1995); more recently, see e.g. Jo Shaw, 'A View of the Citizenship Classics' in Miguel Poiares Maduro and Loic Azoulai (eds), The Past and Future of EU Law (Hart 2010); Phil Syrpis (ed), The Judiciary, the Legislature and the EU Internal Market (Cambridge University Press 2012); Charlotte O’Brien, 'I Trade, Therefore I Am: Legal Personhood in the European Union' (2013) 50 Common Market Law Review 1643; Loic Azolai (ed), The Question of Competence in the European Union (Oxford University Press 2014); Niamh Nic Shuibhne, Panos Koutrakos and Phil Syrpis (eds), Exceptions from EU Free Movement Law: Derogation, Justification and Proportionality (Hart 2016); Niamh Nic Shuibhne, 'Limits Rising, Duties Ascending: The Changing Legal Shape of Union Citizenship' (2015) 52 Common Market Law Review 889; Stephen Weatherill, Law and Values in the European Union (Oxford University Press 2016) 390-2.

21 For a selection of the literature here, see e.g. Tamara Hervey (ed), 'Thirty Years of EU Sex Equality Law' (2005) 12 Maastricht Journal of European and Comparative Law Special Edition 4; Claire McGlynn, Families and the European Union: Law, Politics and Pluralism (Cambridge University Press 2006); Helen Stalford, Samantha Currie and Samantha Velluti (eds), Gender and Migration in 21st Century Europe (Ashgate 2009); Eugenia Caracciolo Di Torella and Anniek Masselot, 'Work and Family Life Balance in the EU Law and Policy 40 Years on: Still Balancing, Still Struggling' (2013) 2 European Gender Equality Law Review 6; Charlotte O’Brien, 'The EU Speaks the Language of Gender Equality but only with a Male Voice' (March 2016) <http://ukandeu.ac.uk/the-eu-speaks-the-language-of-gender-equality-but-with-a-male-voice>.

22 Interviews were conducted by Sheldon as part of the AHRC project noted above. Interviewees determined whether they should be cited by name or just by role and, prior to publication, were invited to give approval for any specific quotations.

23 In Scotland, abortion is subject to common law prohibitions.

$24 \mathrm{R}$ (Smeaton) v SS Health and Others [2002] EWHC 610 (Admin), para 332, per Munby J. 
intent, shall be guilty of an offence and being convicted thereof shall be liable to be kept in penal servitude for life.

59 Whosoever shall unlawfully supply or procure any poison or other noxious thing, or any instrument or thing whatsoever, knowing that the same is intended to be unlawfully used or employed with intent to procure the miscarriage of any woman, whether she be or be not with child, shall be guilty of an offence, and being convicted thereof shall be liable to imprisonment for a term not exceeding five years.

The 1861 Act is widely recognised to be badly outdated and in general need of fundamental reform. ${ }^{25}$ It was the product of an all-male Parliament, selected by an entirely male electorate. ${ }^{26}$ It reflects the moral conservativism and gender norms of an era when women were yet to be recognised as full legal persons ${ }^{27}$ and when the fact of having authored a treatise on contraception was sufficient justification for a woman's child to be taken out of her care. ${ }^{28}$ The offence of 'unlawful procurement of miscarriage' can be committed from implantation (some 6-12 days after fertilisation) on pain of the harshest penalty for abortion foreseen anywhere in Europe. ${ }^{29}$

The harsh effects of these draconian provisions have been mitigated elsewhere in the UK by virtue of the Abortion Act 1967, which broadened access to abortion services under conditions of strict medical control. ${ }^{30}$ The 1967 Act does not apply in Northern Ireland. Rather, the small number of legal abortions performed within the jurisdiction each year are carried out on the basis of $\mathrm{R} v$ Bourne (1938). Under Bourne, 'procurement of miscarriage' is considered not to be 'unlawful', and therefore not an offence under the 1861 Act, where it is performed for the purpose of 'preserving the life of the mother'. This phrase has been found to mean that a termination is necessary in order to prevent the woman from becoming a 'mental and physical wreck', 31 a test which leaves 'plenty of loose ends and ample scope for clarification'.32

While Bourne was afforded a relatively expansive interpretation in the English courts, permitting a considerable relaxation of access to abortion before $1967,{ }^{33}$ the same has not been true in Northern Ireland. Here, doctors have historically been more reluctant to perform abortions and courts have offered a more restrictive reading of the test, ${ }^{34}$ with

25 Law Commission, Reform of Offences Against the Person: A Scoping Consultation Paper Consultation Paper (Law Com No $217 \quad$ 2014) <www.lawcom.gov.uk/wp-content/uploads/2015/06/cp217_ offences_against_the_person.pdf $>$. Abortion offences were excluded from the Law Commission's review on the basis that they raise broader policy issues.

26 Full female franchise was achieved in the Equal Franchise Act 1928.

27 Until the Married Women's Property Act 1882, a married woman was not permitted to own, buy or sell property in her own right.

28 In re Besant (1878) 11 Ch D 508.

29 Kerstin Nebel and Steffen Hurka, 'Abortion: Finding the Impossible Compromise' in Christoph Knill, Christian Adam and Steffen Hurka (eds), On the Road to Permissiveness? Change and Convergence of Moral Regulation in Europe (Oxford University Press 2015).

30 For an account of the regulatory challenges posed to the Abortion Act 1967 by the use of abortion pills, see Sally Sheldon, 'British Abortion Law: Speaking from the Past to Govern the Future' (2016) 79(2) Modern Law Review 283.

31 R v Bourne [1938] 3 All ER 615.

32 Lord Diplock, RCN v DHSS [1981] 1 All ER 545 (QBD, CA and HL), 567.

33 See, generally, John Keown, Abortion, Doctors and the Law (Cambridge University Press 1988); Bernard Dickens, Abortion and the Law (Macgibbon \& Key 1966).

34 See $\operatorname{Re} A M N H$, unreported judgment of the High Court (Mac Dermott LJ), 21 January 1994, where the judge noted that the adverse effects to a woman's health must be 'real and serious'. Medical opinion towards abortion appears to be softening: Colin Francome and Wendy Savage, 'Attitudes and Practice of Gynaecologists towards Abortion in Northern Ireland' (2011) 31(1) Journal of Obstetrics and Gynaecology 50. 
guidance for health and social care professionals issued by the Department of Health (DoH) (formerly known as the Department of Health, Social Services and Public Safety (DHSSPS)), explaining that a termination will only be lawful where continuance of the pregnancy threatens the life of the woman, or would adversely affect her physical or mental health in a manner that is 'real and serious' and 'permanent or long term'. A doctor must form an opinion that this condition is met in 'good faith', with this 'based upon reasonable grounds and with adequate knowledge'. ${ }^{35}$ Just a few dozen women each year are deemed to meet these conditions. ${ }^{36}$

This leaves the vast majority of women facing unwanted pregnancies within Northern Ireland without access to lawful domestic services and just three other options. First, a woman can continue with the pregnancy, with all that entails for her ability to shape her own future (in terms of continuing her education, her career or meeting existing caring commitments) and with the stigma that may follow for a very young or unmarried mother in the context of small, tight-knit and, regardless of any ongoing liberalisation in public opinion noted above, often morally conservative communities.

Second, if she is able to rearrange other commitments, make the necessary excuses to be away and find the required funds in time, she can access legal abortion services outside the jurisdiction, most commonly in England. ${ }^{37}$ Over 800 women each year take this option. ${ }^{38}$ However, not all women are able to travel: Audrey Simpson, former director of the Family Planning Association in Northern Ireland (FPANI), offers the example of a client, pregnant by rape by a member of a paramilitary group and simply unable to disappear for 24 hours. ${ }^{39}$ More commonly, the $f_{0}, 600-f_{2} 2000$ required for the combined cost of procedure, travel and accommodation will not be within the means of all, with expenses mounting further where the pregnancy is experienced by a minor in need of accompaniment or where a woman requires an abortion later in pregnancy. ${ }^{40}$ Women are not eligible to have any of these costs met by the National Health Service. ${ }^{41}$ This leaves some to ration their children's food or electricity meter payments while they save for a

35 DHSSPS, Guidance for Health and Social Care Professionals on Termination of Pregnancy in Northern Ireland (DHSSPS March 2016) <www.health-ni.gov.uk/publications/guidance-hsc-professionals-termination-pregnancynorthern-ireland $>$ paras $2.7-2.8$.

36 Just 30-50 abortions are performed each year in state health facilities, with a small but unknown further number taking place within the Marie Stopes clinic in Belfast. Numbers have fallen from an earlier average of 70-100 per year (until the mid-2000s), a fact that Horgan attributes to the chilling effect of government guidelines. See Goretti Horgan, 'A Holy Alliance? Obstacles to Abortion Rights in Ireland North and South' in Aideen Quilty, Sinéad Kennedy and Catherine Conlon (eds), The Abortion Papers Ireland vol 2 (Cork University Press 2015).

37 For a discussion of this as an 'outsourcing' of reproductive healthcare for women in the Republic of Ireland, see Ruth Fletcher, 'Peripheral Governance: Administering Transnational Healthcare Flows' (2013) 9 International Journal of Law in Context 160. See also Nelleke Koffeman, Morally Sensitive Issues and Cross-Border Movement in the EU (Intersentia 2015); I Glenn Cohen, Patients with Passports: Medical Tourism, Law and Ethics (Oxford University Press 2015) 318-21, 347-56; and I Glenn Cohen, 'Circumvention Tourism' (2012) 97 Cornell Law Review 1309.

38833 in 2015, representing a significant decline on the 1280 who accessed English services in 2004. Department of Health, Abortion Statistics, England and Wales: 2015 (June 2016).

39 Interview.

40 FPANI Women's European Platform and Alliance for Choice, Submission of Evidence to the CEDAW Committee Optional Protocol: Inquiry Procedure (FPANI 2010).

$41 R$ (A and B) v Secretary of State for Health [2015] EWCA Civ 771. A decision on an appeal to the Supreme Court is currently pending. It has been suggested that Scotland might offer free care to Northern Irish women: Siobhan Fenton, 'Scotland Considering Offering Northern Irish Women Free Abortions, Nicola Sturgeon Says' The Independent (18 November 2016) <www.independent.co.uk/news/uk/home-news/scotlandconsidering-offering-northern-irish-women-free-abortions-nicola-sturgeon-says-a 7424736.html>. 
termination, and others to borrow money from backstreet lenders at exorbitant interest rates. ${ }^{42}$ In the words of Horner $J$, the restrictions on abortion thus '[bite] on the impoverished but not the wealthy [. . smacking] of one law for the rich and one law for the poor'. ${ }^{43}$

Faced with this reality, a substantial number of women take the third option: they attempt to resolve their problem within Northern Ireland. Historically, on occasion, this has involved concealed pregnancy and infanticide, as well as the use of a range of abortion methods of highly variable risk and efficacy - including syringes filled with hot soapy water or disinfectant, or ingestion of lead plaster or the herb, penny royal. ${ }^{44}$ While such dangerous methods are in less common use today, they have not been entirely eradicated. The Abortion Support Network (ASN), which offers support to women facing unwanted pregnancies in Northern Ireland, reports contacts:

... from women who have drunk bleach and floor cleaner, and who have gone and gotten three packets of birth control pills and taken them with a bottle of gin, and taken all the pills in her medicine cabinet. We had a woman who had gone out and bought heroin in the hopes that it would make her miscarry. We heard from a mother of four who told us matter-of-factly: 'I'm trying to figure out how to crash my car to cause a miscarriage but not permanently injure myself or die. 45

Today, however, a Northern Irish woman seeking to end her own pregnancy is more likely to rely on abortion pills sourced online and this was the path chosen by the women in the prosecutions noted above. Our focus in this paper is on the legal regimes surrounding this practice and, in particular, on the work of two key groups, which are playing a very significant role in offering telemedical abortion services to women in Northern Ireland: WoW and WHW. ${ }^{46}$

DoH guidance notes that use of abortion pills obtained via the internet is 'likely' to be an offence under the Offences Against the Person Act 1861.47 This phrase acknowledges that there are circumstances where such use might, on the contrary, be lawful. One clear-cut case would be where a woman who used the pills was not pregnant at the time that she took them: if so, she would not commit an offence as a principal under s 58. Secondly, whether abortion pills are 'poisons' or 'noxious substances', which thus fall within the ambit of $\mathrm{s} 58$ is a question of fact, to be determined by a jury. This point has not been tested in the Northern Irish courts, with the conviction above having proceeded on the basis of a guilty plea from the woman concerned. However a Queensland Court acquitted a woman who had been prosecuted under a similarly worded law, apparently on the basis that pills which had been safely used by millions of women

42 Interview, Mara Clarke, director of the ASN, a charity that offers practical support to women facing unwanted pregnancies from Northern Ireland, the Republic of Ireland and the Isle of Man. Clarke added that $€ 600$ borrowed one month could mean needing to pay $€ 900$ a month later.

43 Northern Ireland Human Rights Commission's Application (n 8), para 142.

44 Leanne McCormick, “No Sense of Wrongdoing”: Abortion in Belfast 1917-1967' (2015) 49(1) Journal of Social History 125.

45 Interview. Colin Francome, Abortion in the USA and the UK (Ashgate 2004) noted that 11\% of Northern Irish GPs had seen evidence of attempts at amateur abortion.

46 <www.womenonweb.org>; and <https://womenhelp.org>.

47 DHSSPS (n 35) para 6.7. 
worldwide could not, as a matter of fact, be considered 'poisons' or 'noxious'. ${ }^{48}$ Finally, there is also one further, important possibility that we consider in more detail below: whether a woman treated by a doctor who is based in another country and who relies on that doctor's evaluation of the likely impact of continuing the pregnancy on her physical or mental health might fall within the exception carved out by Bourne. ${ }^{49}$

\section{Abortion by telemedicine within the EU}

Sourcing medication online can be a risky business given the difficulty of identifying reputable suppliers who will send authentic medicines, the potential lack of adequate screening for contraindications, and the variable quality of information supplied as to correct use. At the time of writing, an internet search for 'buy abortion drugs online' generates over 50 million hits, bringing up the websites of many companies prepared to sell and ship pills to Northern Ireland, some highlighting that no prescription is needed. Analyses of purported abortion pills obtained from a number of websites have found that some do not contain the relevant active ingredients, while other sites ship nothing at all. ${ }^{50}$ Further, even where the correct medicines are supplied, not all sites offer appropriate information about contraindications to use, how to take the pills properly, or how to manage any side effects or adverse outcomes. DoH guidance highlights the general dangers involved in online purchase:

There are a number of websites which sell abortifacient drugs. Some use online or telephone based questionnaires to test whether the woman is an appropriate subject for the service offered; many do not. There is no guarantee that drugs supplied by these websites are what they are purported to be, and there is no effective medical supervision of any woman who decides to use them. ${ }^{51}$

However, these blanket claims ignore important differences between the various groups who supply pills and local networks have played a vital role in helping women in Northern Ireland to identify reputable providers. While we acknowledge the general dangers of sourcing medicines online, we focus on the work of two specific suppliers for whom there is evidence to support the safety of the telemedical service which they offer: WoW and WHW. We begin by setting out what is known regarding the incidence of the use of abortion pills in Northern Ireland, before providing some more detail regarding WoW and WHW's work, and the safety of the service which they offer.

\section{THE INCIDENCE OF HOME USE OF ABORTION PILLS IN NI}

A recent study has revealed that in a period of six years (2010-2015), 5650 women across Northern Ireland and the Republic of Ireland requested abortion pills from WoW, one of the two providers discussed in this paper, with the numbers of online consultations more

48 We consider the safety of the pills, including when supplied by telemedicine, below (nn 63-81). It should be noted that UK law is less favourable to such a finding in one important respect. Unlike the offence under the 1861 Act, an offence exists in Queensland even where a woman is not pregnant. The trial judge relied on this fact in explaining to the jury that, as such, 'noxious' must mean that a substance should be 'noxious' to the woman herself: $R v$ Brennan and Leach (unreported, 14 October 2010). The early English case law on the meaning of 'noxious' provides limited guidance in this context, consisting of decisions of lower courts on very different facts, see, generally, Dickens (n 33) 62-9.

49 Bourne (n 31).

50 E.g. WoW's site lists over 100 'scam' sites: <www.womenonwaves.org/en/page/974/warning--fake-abortionpills-for-sale-online $>$.

51 DHSSPS (n 35) para 6.6. 
than doubling over that period. In 2015, 1438 women were treated. ${ }^{52}$ While it is impossible to disaggregate this data, on the basis of their respective populations it is reasonable to assume that up to one-third of these women came from Northern Ireland and our interviews confirmed that WoW treats women from across all regions of the island of Ireland. The more recently established WHW will not share the numbers of pills supplied, emphasising that it is the requests for help that illustrate the true scale of the problem. They likewise refer to women on the island of Ireland as one group, describing 'daily contacts' 'from all over [and] . . . from every age bracket. We have women writing for their daughters, I've had one woman of over 40, and we've had immigrants. ${ }^{5} 53$ Further, regular media reports detail use of abortion pills within Northern Ireland, ${ }^{54}$ and over 200 people have signed an open letter stating that they had either used the pills themselves to end a pregnancy, or had helped another to do so. ${ }^{55}$

This suggests that the use of abortion pills sourced online is likely to offer a substantial part of the explanation for the decline in numbers of women travelling to England to end pregnancies. Only 833 women in 2015 gave a Northern Irish address at an English clinic, compared to the 1280 who had done so in $2004 .{ }^{56}$ While these specific figures are unreliable, with some women likely to give false addresses in an attempt to conceal their identities or to access NHS funding, this reduction is so pronounced as to suggest real change.

Mara Clarke is director of the ASN, a charity which provides help to women facing unwanted pregnancies in Northern Ireland, the Republic of Ireland and the Isle of Man. She notes an upward trajectory in the number of telephone calls received over the last three years from everywhere except Northern Ireland. ${ }^{57}$ Her tentative explanation is that this reflects the number of women accessing abortion pills directly over the internet, with no need for support from ASN. Noting that the women who contact them are increasingly well informed regarding the existence of abortion pills, with many of them also aware of the work of WoW and WHW, she suggests that information regarding the pills would travel more quickly within the smaller, close-knit Northern Irish community than it would elsewhere. ${ }^{58}$ This was confirmed by Audrey Simpson, former director of the FPANI, who told us:

... there's no doubt that women are using [the pills] much more than they did.

It's much more widely known and Northern Ireland has very close knit communities - knowledge spreads through communities. If you can get it for 60-70 pounds, women don't even care if it's safe. As far as they are concerned, it's worth the risk, they just need to end the pregnancy. 59

52 Abigail Aiken, Rebecca Gomperts and James Trussell, 'Experiences and Characteristics of Women Seeking and Completing at-Home Medical Termination of Pregnancy through Online Telemedicine in Ireland and Northern Ireland: A Population-based Analysis' (2016) BJOG: An International Journal of Obstetrics and Gynaecology online first: doi:10.1111/1471-0528.14401.

53 Founding member, WHW, interview.

54 E.g. Henry McDonald, 'Abortion Activist - "I'll still Help Northern Irish Women Buy Pills" The Guardian (5 April 2016) <www.theguardian.com/uk-news/2016/apr/05/abortion-activist-goretti-horgan-i-will-stillhelp-northern-irish-women-buy-pills $>$.

55 Ibid.

56 Department of Health (n 38).

57143 calls were received from Northern Ireland in 2013; 141 in 2014; and 98 by October 2015. This is in the context of a rising number of calls overall: 364 in 2014; 552 in 2014; and over 500 by October 2015. Mara Clarke, interview.

58 Ibid.

59 Interview. 
Clarke also notes that activists in Northern Ireland have been particularly effective in directing women towards safe service providers. As the artist and activist, Emma Campbell, explains:

We try to put in information about the pills in every press release, everything we do, we encourage sharing of that information - online, in social media, getting stories into papers ... We put up stickers on backs of doors in toilet cubicles and also in shopping centres. We do banner drops across the motorway. We point women to WoW and WHW. If anyone contacts us directly, we tell what we know, highlighting that we are not healthcare professionals but that we've been trained. ... [We] tell them it's the safest thing they can do. After that, they go online, do the questionnaire, get the drugs shipped straight to their own address in Northern Ireland. They will arrive within two weeks. ${ }^{60}$

\section{THE SERVICE OFFERED BY WOW AND WHW}

WoW and WHW are online collectives made up of doctors and trained volunteers. Each group is strongly motivated by concerns for social justice, reproductive health and solidarity with women facing unwanted pregnancies. ${ }^{61}$ Following an online consultation that screens for a small number of contraindications, each group will supply mifepristone and misoprostol (which, throughout, we refer to as 'abortion pills') for use during the first nine weeks of pregnancy to women in countries where abortion is illegal. ${ }^{62}$ Each provides clear instructions as to correct use and advice regarding the symptoms which would require women to access aftercare. The safety of abortion pills is well established ${ }^{63}$ and each group follows a well-established treatment protocol that is in widespread use elsewhere in the UK, ${ }^{64}$ with the only significant variation being that the woman will be able to take the pills at home at the time most convenient to her (perhaps when her children are at school or her partner or a friend can be with her). Advice and support is available by email for as long as the woman needs it.

Each group has been established in a way that takes careful account of relevant law. For example, WoW is incorporated in Canada, has offices in the Netherlands, prescribes the pills from a third country such as Austria, and arranges for them to be shipped from a reputable supplier of pharmaceuticals in India. It complies with all relevant regulations in each of these countries. Each group requests a donation of $€ 60-90$ for the treatment, asking that the woman consider giving a greater amount if she can afford it (so as to

60 Interview.

61 Interviews with two members of WoW and three members of WHW. See further: <www.womenonweb.org/en/page/544/in-collection/6901/why-is-this-help-service-needed>; <https://womenhelp.org/en/page/346/women-help-women-is-about-access--information-and-activism>; and Rebecca J Gomperts, Kinga Jelinska, Susan Davies, Kristina Gemzell-Danielsson and Gunilla Kleiverda, 'Using Telemedicine for Termination of Pregnancy with Mifepristone and Misoprostol in Settings Where There is No Access to Safe Services' (2008) 115(9) BJOG: An International Journal of Obstetrics and Gynaecology 1171.

62 The treatment protocol used by WoW and WHW, and in use in clinics across the UK, involves the sequential administration of mifepristone (an antiprogestin, which acts to block the progesterone receptors causing the uterine lining to break down and increasing the sensitivity of the uterus to prostaglandins), followed by misoprostol (a prostaglandin analogue, which induces uterine contractions that expel the contents of the womb).

63 World Health Organization, Model List of Essential Medicines 19th List (WHO 2015); Royal College of Obstetrics and Gynaecology, The Care of Women Requesting Induced Abortion (Evidence-based Clinical Guideline No 7 , RCOG 2011) <www.rcog.org.uk/globalassets/documents/guidelines/abortion-guideline_web_1.pdf>; see further below (nn 65-81).

64 RCOG (n 63). 
support access to services for others) and waiving it if she cannot. Women are screened for contraindications before pills are supplied and are offered ongoing support by email. The adequacy of such arrangements was tested in the Austrian courts in an action, apparently instigated by the Irish government, attempting to prevent Rebecca Gomperts of WoW from supplying abortion pills to women in the Republic of Ireland. The resulting judgment confirmed the legality of Dr Gomperts prescribing pills from Austria, with the service meeting the relevant legal test in Austrian law for a 'personal and direct assessment of the patient'. ${ }^{65}$ The Austrian court took account of the fact that women who could not legally obtain an abortion were in a particularly desperate situation, finding that WoW's work made an overall contribution to Irish women's health and survival. 66 The same reasoning would apply to the situation in Northern Ireland, where the law is similarly restrictive.

Telemedical abortion services are subject to legal restrictions in many parts of the world. However, in places where no such barriers exist, it has been established that they can be safe and effective. ${ }^{67}$ Abortion pills are extremely acceptable to women, including when used at home. ${ }^{68}$ While women on the island of Ireland who had accessed pills via WoW commonly reported serious mental stress caused by their pregnancies and inability to afford travel to access abortion services elsewhere, almost all felt that home use of pills had been the right choice (97 per cent) and one that they would recommend to someone else (98 per cent). ${ }^{69}$

Few women experience serious side effects as a result of early abortion using pills and pain is generally manageable using over-the-counter analgesia. ${ }^{70}$ One large study found that rates of hospital admission due to complications are extremely low, ranging from 0.04 per cent to 0.3 per cent. ${ }^{71}$ Serious infections requiring hospitalisation are very rare and it is only in the most extreme of circumstances (estimated at just 0.03 per cent of cases) that women require transfusion to replace excessive blood loss. ${ }^{72}$ Haemorrhage can be life-threatening if left untreated and WoW and WHW advise women to plan for it, emphasising that this makes a planned miscarriage considerably safer than if the same thing occurs spontaneously. This is an important limitation of the care that can be provided through a telemedical service: while each group provides ongoing support and advice by email, the medical treatment that they offer necessarily ends with provoking a miscarriage, with women obliged to seek any necessary aftercare locally. Research suggests, however, that, given the appropriate information, women can safely self-assess to confirm that the termination is complete and if further care is needed. ${ }^{73}$ Moreover, this is also the case for early abortions elsewhere in the UK, where women will frequently take

65 UVS 30.1.2012, UVS-06/9/2829/2010-23.

66 Ibid.

67 Daniel Grossman, Kate Grindlay, Todd Buchacker, Kathleen Lane and Kelly Blanchard, 'Effectiveness and Acceptability of Medical Abortion Provided through Telemedicine' (2011) 118(2) Obstetrics and Gynecology 296.

68 Regina Kulier, Natalie Kapp, A Metin Gülmezoglu et al, 'Medical Methods for First Trimester Abortion' (2011) 11 Cochrane Database of Systematic Reviews Art No CD002855.

69 Aiken et al (n 52).

70 RCOG (n 63).

71 Kelly Cleland and Nicole Smith, 'Aligning Mifepristone Regulation with Evidence: Driving Policy Change Using 15 Years of Excellent Safety Data' (2015) 92 Contraception 179.

72 Ibid.

73 Kevin S Oppegaard, Erik Qvigstad, Christian Fiala, Oskari Heikinheimo, Lina Benson and Kristina GemzellDanielsson, 'Clinical Follow-up Compared with Self-assessment of Outcome after Medical Abortion: A Multicentre, Non-inferiority, Randomised, Controlled Trial' (2015) 385(9969) Lancet 698-704; Gomperts et al (n 61). 
pills in a clinic and then immediately leave in order to arrive home before their miscarriage begins. Those women will also monitor their own health and seek emergency care where needed, albeit with the additional option of seeking further advice or support by telephone or face to face from the clinic where they were treated. Further, women often manage spontaneous miscarriages by themselves at home, with limited medical supervision. Where medical aftercare is required, health care professionals will be unable to tell how an abortion has been provoked ${ }^{74}$ and WoW and WHW advise that there is no need to disclose the use of the pills, as the recommended treatment is the same as for a spontaneous miscarriage. ${ }^{75}$

All of our interviewees confirmed that they were not personally aware of any woman who had suffered negative health consequences as a result of the use of abortion pills and the activists interviewed were confident that they would have heard about any serious issues. We were given just one, albeit second-hand, report of a serious problem. A hospital doctor had contacted the former director of the FPANI in the erroneous belief that her organisation had advised a woman, now in his care, on how to access abortion pills. The woman was reported to be suffering from a 'life-threatening' condition, but no further detail was offered as to whether this was a result of inauthentic medication, incorrect use, or whether she had sought treatment for a recognised side effect of the pills. ${ }^{76}$

While this report raises concerns, an evaluation of telemedical abortion nonetheless needs to compare it to the alternatives available to women, as outlined in the introduction. First, alongside the social, emotional and financial harms that come with continuing an unwanted pregnancy to term are the very real clinical risks of so doing: pregnancy and childbirth carries a significantly higher risk of morbidity and mortality than a safely performed abortion, particularly in early pregnancy. ${ }^{77}$ Second, while this is less well documented, it is also likely that the need to travel to obtain an abortion has negative health consequences. ${ }^{78}$ Northern Irish women who end pregnancies in England will do so slightly later than resident English women, reflecting the problems that some women will face in making arrangements and securing the necessary funds, increasing the risks to their health. ${ }^{79}$ Third, it is well documented that, where unable to access safe abortion services, some women will try other extreme measures to end a pregnancy (some of which we noted above). These are generally either exceedingly dangerous, likely to be ineffective, or both. It is noteworthy here that the availability of abortion pills is credited with making a contribution to the global reduction in the number of women's deaths that

74 DHSSPS (n 35) para 6.8 .

75 This advice is significant in Northern Ireland, where there is a general duty, backed by a maximum 10-year prison term, to report criminal offences. While this potentially captures a healthcare professional who suspects a patient of having procured an illegal abortion, one who chooses not to report could plead that the imperative of medical confidentiality offers 'reasonable excuse' for failing to do so: s 5, Criminal Law Act (NI) 1967; DHSSPS (n 35) para 9.4.

76 Audrey Simpson, interview.

778.5 per 100,000 women died during pregnancy or up to six weeks after giving birth or the end of pregnancy in 2012-2014, MBRRACE-UK, Saving Lives, Improving Mothers' Care (2016) <www.npeu.ox.ac.uk/mbrraceuk/reports>; see further RCOG (n 63).

78 In finding that Ireland's abortion law subjected Amanda Mellett to cruel, inhuman and degrading treatment in forcing her to leave Ireland for an abortion for fatal fetal anomaly, the UN's Human Rights Committee noted: ' $[\mathrm{m}]$ any of the negative experiences she went through could have been avoided if (she) had not been prohibited from terminating her pregnancy in the familiar environment of her own country and under the care of health professionals whom she knew and trusted' (n 9).

79 In 2015, for women resident in England and Wales, 92\% of abortions were carried out at under 13 weeks' gestation and $80 \%$ were at under 10 weeks, compared to $88 \%$ at under 13 weeks and $73 \%$ at under 10 weeks for NI women: Department of Health (n 38). 
result from illegal abortion each year (from 56,000 per year in 2003 to 47,000 per year in 2008), with most deaths occurring in sub-Saharan Africa where abortion pills are not widely available. ${ }^{80}$

There is thus good reason to suggest that telemedical abortion services, as offered by WoW and WHW within Northern Ireland, meet the best standards of patient care and safety that are available given the context in which they are offered. These groups offer women a choice which allows them to avoid the risks of other methods of illegal abortion and the significant physical, emotional, social and financial burdens of continuing an unwanted pregnancy. As noted by the Austrian court cited above, these groups' work makes a material contribution to women's health and survival. ${ }^{81}$ However, controversially, their work also enables women to avoid legal prohibitions on abortion designed to recognise the moral significance of fetal life and to prevent or to condemn its intentional destruction. 82

The discussion above raises a range of important ethical, political and legal questions. In what follows, we focus on just those that relate to the compatibility of Northern Ireland's restrictions on women's access to abortion pills with the entitlements of doctors and patients in EU law. Our focus is on the relevant EU economic law; there are also important considerations of EU human rights law, which we note but do not develop here. The issues raised are both complex, technical legal matters regarding the appropriate interpretation of EU law in this context, and also broader social, ethical and political questions regarding the nature of the EU's internal market law, the role of fundamental human rights in shaping the EU legal order, the possibility for states to recognise and protect fetal life in ways that restrict reproductive rights and impact negatively on women's health, and the means by which EU (health) law alters relationships between doctors, patients and health systems. We now turn to these questions.

\section{EU health law, Northern Irish law and access to abortion services}

Others have considered how European law (which includes EU law and the law of the ECHR) applies to access to information about or the advertising of abortion services. ${ }^{83}$ In SPUC $v$ Grogan, 84 the European Court of Justice (CJEU) decided that abortion constitutes a 'service' within what is now Article 56 of the Treaty on the Functioning of the EU (TFEU) and that women have the right to obtain information regarding abortion services in another jurisdiction. The European Court of Human Rights (ECtHR), in Open Door, similarly recognised that women have a right to information under the ECHR regarding services offered in other states. ${ }^{85}$ The importance of the latter case is explicitly

80 WHO, Unsafe Abortion: Global and Regional Estimates of the Incidence of Unsafe Abortion and Associated Mortality in 2008 (6th edn, WHO 2011).

81 UVS (n 65).

82 For a critical discussion of how successfully the 1861 Act achieves these purposes, see generally, Sally Sheldon, 'The Decriminalisation of Abortion: An Argument for Modernisation' (2016) 36(2) Oxford Journal of Legal Studies 334.

83 See e.g. Elizabeth Spahn, 'Abortion, Speech, and the European Community' (1992) 14 Journal of Social Welfare and Family Law 17-32; Diarmuid Rossa Phelan, 'The Right to Life of the Unborn v Promotion of Trade in Services: The European Court of Justice and the Normative Shaping of the European Union' (1992) 55 Modern Law Review 670.

84 Case C-159/90 The Society for the Protection of Unborn Children Ireland Ltd v Grogan and Others EU:C:1991:378.

85 Open Door and Dublin Well Woman v Ireland (14234/88) [1992] ECHR 68 (29 October 1992): restraining counselling agencies from providing pregnant women with information concerning abortion facilities abroad was held to violate Art 10 of the ECHR. 
recognised in the official DoH guidance on abortion in Northern Ireland, which provides that:

Women may seek advice on access to, or availability of, termination of pregnancy services in other jurisdictions. Information on such services is in the public domain and accessible from a range of sources including magazines, television and the Internet. If requested, health professionals may inform women of the availability of information on these services to ensure that the woman is able to come to a fully informed decision. ${ }^{86}$

While the principle established by Grogan and Open Counselling is significant, these cases date from the late 1980 s and early 1990s, a time of very different technological possibilities, when women would have needed to travel in order to access abortion services in another jurisdiction. Today, however, as described above, the combination of internet-based telemedical provision and abortion pills makes it potentially very safe, as well as considerably cheaper and more convenient, for women to access abortion services without travelling. Indeed, it is important to recall that the position of a woman (in Northern Ireland) who receives a package in the post with the relevant medicines, following a consultation over the internet, is not very different in any respect material to her health to that of a woman accessing early abortion services in an English clinic. As described above, in the case of each woman, the pills will very often take effect outside any health institution and without any medical professionals present, usually in the woman's own home. Each woman is screened for contraindications before pills are offered and each has access to hospital care in the very unlikely event that she should need it. 87

The DoH guidance makes no reference to what information may lawfully be offered regarding the safety of home use of abortion pills or where they may be safely accessed. Indeed, its rather cumbersome language might suggest that guidance has been carefully drafted precisely in order to avoid taking a position on this point: it notes merely the legality of giving advice regarding services offered where the woman is 'present in another jurisdiction'. ${ }^{88}$ We would suggest, however, the provision of accurate information regarding the services offered by WoW and WHW is also potentially captured by the rights at play here, given that each is involved in the provision of lawful services 'in other jurisdictions'. ${ }^{89}$ As such, the guidance might usefully go further in setting out women's rights to accurate information regarding the lawful services thus offered. We return to this point below. ${ }^{90}$

The other hugely significant change since the 1980s is to how EU law interacts with medical treatment and health care. In general, EU law on services has burgeoned since the 1980 s, ${ }^{91}$ including not only a great deal of CJEU case law, but also detailed economic legislation on electronic commerce which applies where services are supplied across a border, with the provider and the recipient in different countries, such as in the work of WoW and WHW. EU law has therefore moved beyond the relatively simple situation at issue in Grogan, which involved interpretation of only the EU Treaty law as it applies to

86 DHSSPS (n 35) para 5.11.

87 See, generally, above (nn 62-4 and accompanying text).

88 DHSSPS (n 35) para 5.13.

89 For a consideration of the legality of provision of information to women resident in the Republic of Ireland about the services offered by WoW and WHW, see Sheldon (n 18).

90 See below (n 189) and accompanying text.

91 See e.g. Siofra O’Leary, 'Free Movement of Persons and Services' in Paul Craig and Graínne de Búrca (eds), The Evolution of EU Law (Oxford University Press 2011); Vassilis Hatzopoulos, Regulating Services in the European Union (Oxford University Press 2012). 
information about services where the service recipient crosses a border. A more dense EU legal environment on services applies today. In addition, although we are not able to cover the technical detail in this paper, the EU's human rights law has also developed enormously, and rapidly, in the past few decades. ${ }^{92}$

More specifically, Hervey and McHale, and others, take the view that 'EU health law' has altered legal relationships between patients, doctors and the state. ${ }^{93} \mathrm{EU}$ law has had effects on some areas of health law since the 1960s, but in the last couple of decades the areas covered by EU law have both broadened and deepened significantly. This justifies conceptualising the relevant legal provisions through the logics of 'EU health law', rather than of EU law more generally. Without going into too much detail here, the general trend of EU health law has been towards the enhancement of patient autonomy and choice, ${ }^{94}$ and the securing of greater professional mobility, including through recognition of the ability of doctors who are licensed to practise in one EU state to treat patients who are in, or are citizens of, other EU states. ${ }^{95}$ There are exceptions to this general trend but, as exceptions, they must be narrowly construed. Whether these trends apply also in their strong form to other transnational legal orders is a question for another paper, but some see an emerging 'global health law' as encompassing entitlements of patients and providers within paradigms of 'medical tourism', which may radically reconfigure arrangements for health services in states across the globe. 96

We now explore the extent to which EU health law supports doctors providing, and women seeking to access, telemedical abortion services. As noted above, our specific focus here is on the work of two groups: WoW and WHW. Whether our legal analysis also

92 See e.g. Steve Peers, Tamara Hervey, Jeff Kenner and Angela Ward, The EU Charter of Fundamental Rights (Hart 2014); Graínne de Búrca, 'The Evolution of EU Human Rights Law' in Craig and de Búrca (n 91).

93 See e.g. Tamara Hervey and Jean McHale, European Union Health Law: Themes and Implications (Cambridge University Press 2015) chs 4, 6, 8, 9 and 11; Tamara Hervey and Calum Young with Louise Bishop, Research Handbook in EU Health Law and Policy (Edward Elgar 2017 forthcoming); Scott L Greer and Tomislav Sokol, 'Rules for Rights: European Law, Health Care and Social Citizenship' (2014) 20(1) European Law Journal 66; Leigh Hancher and Wolf Sauter, EU Competition and Internal Market Law in the Healthcare Sector (Oxford University Press 2012) 53-83, but see 133-7; Wouter Gekiere, Rita Baeten and Willy Palm, 'Free Movement of Services in the EU and Health Care' in Elias Mossialos, Govin Permanand, Rita Baeten and Tamara Hervey (eds), Health Systems Governance in Europe: The Role of European Union Law and Policy (Cambridge University Press 2010); Mette Hartlev, 'Diversity and Harmonisation: Trends and Challenges in European Health Law' (2010) 17(1) European Journal of Health Law 37; Christopher Newdick, 'The European Court of Justice, Transnational Health Care, and Social Citizenship - Accidental Death of a Concept?' (2009) 26 Wisconsin International Law Journal 845; Christopher Newdick, 'Preserving Social Citizenship in Health Care Markets There may be Trouble Ahead' (2008) 2 McGill Journal of Law and Health 93; Chistopher Newdick, 'Citizenship, Free Movement and Health Care: Cementing Individual Rights by Corroding Social Solidarity' (2006) 43 Common Market Law Review 1645; Gareth Davies, 'The Process and Side-effects of Harmonisation of European Welfare States' (Jean Monnet Working Paper 2/06) $<$ www.jeanmonnetprogram.org/paper/the-process-and-side-effects-of-harmonisation-of-european-welfarestates $/>$.

94 Ibid.

95 See e.g. Hervey and McHale (n 93) ch 6; Ellen Kuhlmann, Claudia Maier, Gilles Dussault, Christa Larsen, Emmanuele Pavolini and Marios-Ionuț Ungureanu, 'EU Law, Policy and Health Professional Mobility' in Hervey et al (n 93); Irene Glinos, 'Going beyond Numbers: A Typology of Professional Mobility Inside and Outside the European Union' (2014) 33(1) Policy and Society 25; Mieke Peeters, Martin McKee and Sherry Merkur, 'EU Law and Health Professionals' in Mossialos et al (n 93).

96 See, for a selection, Cohen (n 37); Michael Freeman, Sarah Hawkes and Belinda Bennett (eds), Law and Global Health (Oxford University Press 2014); Lawrence O Gostin, Global Health Law (Harvard University Press 2014); Colleen M Flood and Trudo Lemmens, 'Global Health Challenges and the Role of Law' (2013) 41 Journal of Law and Medical Ethics 9; I Glenn Cohen (ed), The Globalisation of Healthcare: Legal and Ethical Issues (Oxford University Press 2013); Nathan Cortez, 'Patients without Borders: The Emerging Global Market for Patients and the Evolution of Modern Health Care' (2008) 83 Indiana Law Journal 71. 
applies to other groups that offer to supply abortion pills would depend on a case-by-case consideration of the service which they offer including, significantly, the role played by appropriately credentialled medical professionals within it and adherence to best available standards of clinical practice. In our exploration, we bring together two key and interrelated aspects of EU health law: professional regulation and patient autonomy.

\section{Professional Regulation IN EU health LaW}

EU health law (legislation and provisions of the TEU and TFEU, interpreted by the CJEU) seeks to protect and promote the ability of health professionals to operate across internal EU borders. It does not go so far as to construct healthcare professionals, such as the doctors in WoW and WHW, entirely as entrepreneurs operating within an unregulated market of 28 countries. But it does see them as professionals regulated essentially by the state in which they choose to establish themselves, while being able to offer services to consumers (patients) in other member states. ${ }^{97}$

The potentially relevant EU law includes Article 56 TFEU, the 'Services Directive', 98 the Directive on the mutual recognition of professional medical qualifications, ${ }^{99}$ and the e-commerce Directive. ${ }^{100}$ As this latter is the lex specialis, we focus our analytical attention here, although the arguments apply equally to litigation under the other Directives, or Article 56 TFEU. The e-commerce Directive covers provision of services across EU borders, including medical consultations undertaken through a website. ${ }^{101} \mathrm{~A}$ 'service' in EU law must attract remuneration, though this can be provided by a third party, ${ }^{102}$ and the service provider need not be seeking to make a profit. ${ }^{103}$ In general, under the Directive, the rule is that prohibitions on services provision applicable to (health) professionals within the UK must not extend to providers of such services lawfully established in another member state, such as WoW or WHW, ${ }^{104}$ unless justified by objective policy interests.

97 Hervey and McHale (n 93) ch 6. See e.g. Directive 2005/36/EC of the European Parliament and of the Council of 7 September 2005 on the recognition of professional qualifications [2005] OJ L255/22; Directive 2011/24/EU of the European Parliament and of the Council of 9 March 2011 on the application of patients' rights in cross-border healthcare [2011] OJ L88/45; Cases C-286/82 and C-26/83 Luisi and Carbone v Ministero del Tesoro EU:C:1984; Case C-159/90 SPUC v Grogan (n 84); Case C-158/96 Kobll v Union des caisses de maladie EU:C:1998:171; Case C-372/04, R (on the Application of Yvonne Watts) v Bedford Primary Care Trust and Secretary of State for Health EU:C:2005:784; Case C-322/01 Deutscher Apothekerverband eV v 0800 DocMorris NV and Jacques Waterval EU:C:2003:664; Cases C-171/07 and 172/07 Apothekerkammer des Saarlandes (joined party DocMorris) EU:C:2009:316.

98 Directive 2006/123/EC of the European Parliament and of the Council of 12 December 2006 on services in the internal market [2006] OJ L376/36, although actually it excludes health care services, see Article 2(2)(f).

99 Directive 2005/36/EC (n 97).

100 Directive 2000/31/EC of the European Parliament and of the Council of 8 June 2000 on certain legal aspects of information society services, in particular electronic commerce, in the Internal Market (e-commerce Directive) OJ 2000 L 178/1. Implemented in the UK by the Electronic Commerce (EC Directive) Regulations 2002 No 2013.

101 The e-commerce Directive does not apply to 'telephone consultation of a doctor': e-commerce Directive (n 100) Art 1(2), 2(a), referring to Directive 98/43/EC, Art 1(2), and Annex V. Electronic Commerce (EC Directive) Regulations 2002 No 2013, reg 2.

102 Case 352/85 Bond van Adverteerders EU:C:1988:196.

103 Case C-281/06 Jund EU:C:2007:816.

104 Member states 'may not . . . restrict freedom to provide information society services from another Member State’: e-commerce Directive Art 3(2); Electronic Commerce (EC Directive) Regulations 2002 No 2013, reg 4. 


\section{Patient AutONOMY IN EU HEALTH LAW}

What about the legal position of the women who use abortion pills obtained online? EU health law seeks to protect and promote the ability of patients to access medical treatment across internal EU borders. As with professionals, EU health law does not construct patients, including the women seeking to access services from WoW or WHW, solely as consumers able to choose services within an unregulated market of 28 countries. However, EU health law does see patients as autonomous actors enabled by EU law to contract or interact in other ways with service providers established in any EU member state whose regulatory arrangements they choose to trust. ${ }^{105}$ WoW and WHW are providing a 'service' within EU law, even if a particular woman does not pay for it herself, because there is an indirect payment by other women who are able to donate more and who cross-subsidise those who are unable to pay. At the same time, EU health law is attentive to patients' human rights, including the civil and political rights that protect dignity and autonomy often associated with health settings (for instance, rights to consent to medical treatment and to privacy), as well as perhaps the social 'right to health care'. ${ }^{106}$ The consequence of the relevant rules is that patients may in practice escape the regulatory regime of their 'home state' and this has been recognised in EU law since at least the 1980s. ${ }^{107}$ The question, considered in detail below, is whether those rules apply even in situations where the home regulatory regime seeks to impose restrictions grounded in health or consumer protection, or in moral values. All of the above potentially applies also in the context of other transnational trade agreements, including the post-Brexit arrangements in the UK, depending on the precise modalities of the agreements and their applicability to medical services. ${ }^{108}$

The potentially relevant EU law includes Article 56 TFEU, the e-commerce Directive, and the 'Patients' Rights Directive' 2011/24/EU. ${ }^{109}$ The underlying idea behind Directive $2011 / 24 / E U$ is to 'provide rules for facilitating the access to safe and high-quality crossborder healthcare'. ${ }^{110}$ This is in the spirit of free movement of health services within the internal market. The Directive seeks to bring legislative certainty to a phenomenon that had attracted significant litigation based on Article 56 TFEU: cross-border patient movement within the EU. ${ }^{111}$ Despite its name, however, there are in fact no substantive entitlements of patients (or indeed health care professionals) within the Directive that

105 Hervey and McHale (n 93) chs 4 and 6; Greer and Sokol (n 93); Giacomo Di Federico, 'Access to Healthcare in the Post-Lisbon Era and the Genuine Enjoyment of EU Citizens' Rights' in Lucia Rossi and Federico Casolari (eds), The EU after Lisbon: Amending or Coping with the Existing Treaties (Springer 2014). See e.g. Directive 2011/24/EU (n 97); Cases C-286/82 and C-26/83 Luisi and Carbone (n 97); Case C-159/90 SPUC v Grogan (n 84); Case C-158/96 Kohll (n 97); Case C-385/99 Müller-Fauré/Van Riet EU:C:2003:270; Case C-372/04 Watts (n 97); Case C-8/02 Leichtle EU:C:2004:161; Case C-444/05 Stamatelaki EU:C:2007:231; Case C-173/09 Elchinov EU:C:2010:581; C-512/08 Case C-490/09 Commission v France (Major Medical Equipment) EU:C:2010:579; Commission v Luxembourg (Medical Laboratory Tests) EU:C:2011:34.

106 Hervey and McHale (n 93) chs 7 and 8.

107 See Cases C-286/82 and 26/83 Luisi and Carbone (n 97); Case C-159/90 SPUCv Grogan (n 84). See also, in the English context, Rv Human Fertilisation and Embryology Authority ex parte Blood [1997] 2 All ER 687, and the discussion in Derek Morgan and Robert Lee, 'In the Name of the Father? Ex parte Blood: Dealing with Novelty and Anomaly' (1997) 60 Modern Law Review 840; Tamara Hervey, 'Buy Baby? The European Union and Regulation of Human Reproduction' (1998) 18 Oxford Journal of Legal Studies 207.

108 On such 'medical tourism', see e.g. Cohen (n 37); I Glenn Cohen, 'Medical Tourism and Global Justice' and 'The Proportionality Problem in Cross-Border Reproductive Care' both in Cohen (n 96); Cortez (n 96).

109 The 'General Services Directive' 2006/123/EC (n 98) does not apply to health services.

110 Directive 2011/24/EU (n 97) Art 1.

111 See case law cited above (nn 97 and 105). 
apply to the activities of WoW and WHW. The Directive does not have any explicit provisions about remote arrangements for medical treatment. ${ }^{112}$ Even the mutual recognition of prescriptions provisions ${ }^{113}$ are applicable only where a prescription has been issued in one member state and the patient seeks to have it fulfilled in another member state, which is not the case here.

Instead, a woman in Northern Ireland seeking to rely on EU law, for example, in defending a criminal prosecution or challenging any attempts to restrict her access to the abortion services offered by WoW or WHW, ${ }^{114}$ would have to rely on either the e-commerce Directive, or the general rule in Article 56 TFEU. Such measures of EU health law give rights to recipients of services. They require that 'restrictions' on free movement of services must be justified by objective public interests.

\section{RESTRICTIONS ON PATIENT AND PROFESSIONAL AUTONOMY IN EU HEALTH LAW}

A preliminary question to be determined is whether the issue at stake here concerns freedom to provide and receive services or, rather, the free movement of goods. It could be argued that the threat of criminal prosecution for supplying, procuring or using abortion pills to procure a miscarriage is not necessarily restricting the provision of the service of the consultation per se, as an offence is only potentially committed at the point that abortion pills are supplied, procured or used. If so, the restriction or obstacle to trade would not be the provision or receipt of the service itself: WoW and WHW may lawfully provide consultations inasmuch as these are only imparting information about the options available to a pregnant woman in Northern Ireland, in much the same way that information about travelling to England for abortion services was secured by EU law in the Grogan case. Any legal issues would then fall to be considered under EU rules on free movement of goods. Here the relevant legislation includes the significant body of EU law on marketing authorisation for pharmaceuticals. ${ }^{115}$

The implications of this EU legislation for national consumer/patient protection and health policies were at issue in the DocMorris case. ${ }^{116}$ An internet pharmacy lawfully established in the Netherlands offered prescription and non-prescription medicines to patients in Germany. German law prohibited the private importation of medicines, which were required by German law to be handled only through pharmacies. The CJEU held that national rules implementing EU consumer/patient protection legislation by requiring that pharmaceuticals must have marketing authorisation are not 'restrictions' on free movement of goods where they apply to medicines not authorised in Germany. Otherwise, the EU pharmaceutical marketing authorisation system, which requires an authorisation for each member state, could be easily circumvented. Neither patients nor health professionals may autonomously deploy EU free movement law so as to avoid the protection provided by that EU legislation.

The CJEU held that an absolute prohibition on the sale of authorised nonprescription medicines through the internet is an unjustified breach of EU free movement law. Such a prohibition on prescription medicines, including where prescribed

112 Indeed Directive 2011/24/EU (n 97), Recital 17 says as much: 'This Directive should not affect Member States' rules concerning the sale of medicinal products and medical devices over the Internet.'

113 Directive 2011/24/EU (n 97) Art 11.

114 The availability of EU law as a defence in a criminal prosecution has been recognised since the 1970s, see Case 148/78 Pubblico Ministero v Ratti EU:C:1979:110.

115 In particular, Directive 2001/83/EC on the community code relating to medicinal products for human use OJ $2001 \mathrm{~L} 311 / 67$, as amended.

116 Case C-322/01 DocMorris (n 97). 
by a doctor established in another member state, is a prima facie breach, which must be justified. ${ }^{117}$ The pills supplied by WoW and WHW are authorised for marketing in the UK and, indeed, are used in Northern Irish abortion services. If EU free movement of goods law is deemed to apply to WoW and WHW's work in Northern Ireland, the question will be whether the restriction on free trade in pharmaceuticals entailed in Northern Ireland's abortion law is justified under EU law and we consider this matter below.

However, given the nature of the transaction at issue, to argue that this is really about products, and not the e-commerce service of remote provision of abortion services across borders, would seem far-fetched. The consultation, the issuing of the prescription and the provision of the pills are so closely bundled ${ }^{118}$ that the threat of prosecution must be understood as prohibiting or at least significantly impeding ('restricting' to use the term of the Directive) the health professional from providing, and the woman from receiving, the service across internal EU borders. The legal concept of a 'restriction' under the e-commerce Directive, and EU case law on the Treaty rules, is a broad one. It encompasses any rule or practice which impedes or makes it more difficult for a service to be received across borders in the EU. ${ }^{119}$ Where professional qualifications regulation is such a 'restriction', qualifications from one member state must be recognised in other member states, again unless justified. ${ }^{120}$

To summarise: current Northern Irish law constitutes a prima facie breach of EU freedom of movement provisions, most likely on services. We turn now to the key question of whether this breach can be justified.

\section{DEROGATIONS FROM PATIENT AND PROFESSIONAL AUTONOMY IN EU HEALTH LAW}

Member states may derogate from the rule prohibiting restrictions on professionals based in one member state from offering e-commerce services in another, ${ }^{121}$ or on patients from receiving those services, if necessary for 'public policy, in particular the prevention, investigation, detection and prosecution of criminal offences ... public health . . the protection of consumers'; or where the service presents a 'serious and grave risk of

117 Para 124.

118 See, for a parallel, the CJEU's approach to interpretation of a consumer contract involving bundled services and (health-related) products in Case C-108/09 Ker-Optika bt v ÀNTSZ Dél-dunántúli Regionális Intézete EU:C:2010:725.

119 A 'restriction' in this context covers 'any national rules which have the effect of making the provision of services between Member States more difficult than the provision of services purely within a Member State', see Case C-444/05 Stamatelaki EU:C:2007:231, para 25. See also Case C-186/87 Cowan v Le Trésor Public EU:C:1989:47, paras 15-17; Case C-76/90 Säger v Dennemeyer EU:C:1991:331, para 12; Case C-43/93 Vander Elst U:C:1994:310, para 14; Case C-381/93 Commission v France EU:C:1994:370, para 17; Case C-272/94 Guiot and Climatec EU:C:1996:147, para 10; Case C-158/96 Kobll (n 97) para 33; Case C-368/98 Vanbraekel EU:C:2001:400, para 45; Case C-157/99 Geraets-Smits/Peerbooms EU:C:2001:404, para 61; Case C-372/04 Watts (n 97) para 94. See Hervey and McHale (n 93) 77-83; Gekiere et al (n 93); Hancher and Sauter (n 93).

120 This is a long-established principle of EU law, see Case 71/76 Thieffry EU:C:1977:65; Case 340/89 Vlassopoulou EU:C:1991:193 and is also enshrined in EU legislation, see Directive 2005/36/EC (n 97).

121 E-commerce Directive (n 100), Art 3(4). Electronic Commerce (EC Directive) Regulations 2002 No 2013 , reg 5. 
prejudice to those objectives'. ${ }^{122}$ In general, and particularly where an area is not harmonised by EU legislation, the CJEU respects national decisions about acceptable risks to health ${ }^{123}$ or consumers, and national articulations of morality. Nonetheless, and importantly, derogations must not violate mutual recognition of protections in another member state where equivalent safeguards can be found, 124 must respect mutual recognition of professional qualifications where provided for by EU legislation, ${ }^{125}$ and must be part of proportionate, consistent and evidence-based national law and policy, designed to achieve its stated objectives. ${ }^{126}$ In this regard, the CJEU gives considerably less discretion to national decision-makers than the ECtHR, Strasbourg, or indeed the WTO decision-making authorities. Justifications for departing from EU free trade law, including their implications for professional and patient autonomy, are narrowly interpreted as exceptions to a rule. When interpreting the relevant EU law (including internal market legislation), compliance with the protection of human rights, long

$122 \mathrm{Ibid}$. There is a procedural element to the EU's derogation rules, which might create some additional problems for the UK, should it seek to rely on them in this context. Under the e-commerce Directive, Art 3(4)(b), a member state seeking to rely on the derogation must request the other member state to take measures to protect the relevant public interest and notify the European Commission. European Commission reports suggest there have been no notifications on protection of minors, or protection of human dignity: see European Commission <http://ec.europa.eu/internal_market/e-commerce/docs/expert/presentation _en.pdf $>$ and the European Commission's Staff Working Document on online services in the single market SEC(2011) 1641 Final. The UK's implementing regulations include the obligation of notification, except where criminal proceedings are at issue, see Electronic Commerce (EC Directive) Regulations 2002 No 2013, reg 5(5). It is conceivable that this breaches EU law, but criminal matters are outside the scope of the Directive, as it is internal market law, so the UK statutory position here is probably defensible. In a case involving a different Directive, concerning technical barriers to trade in goods (Directive 83/189/EC OJ 1983 L 109/8), the CJEU has not accepted the argument that a breach of such notification obligations grants an individual a defence in criminal proceedings, see Case C-226/97 Lemmens EU:C:1998:296. In any event, it is not obvious that the two situations are sufficiently analogous to rely on this case law concerning the EU's regulation of technical barriers to trade in goods. There is a remote possibility that, if notification has not taken place, the obligation to notify may have incidental effects on the legal position of private parties, here the women being prosecuted, see Case C-194/94 CLA Security EU:C:1996:172; Case C-443/98 Unilever Italia EU:C:2000:496; and Case C-159/00 Sapod Audiac EU:C:2002:343. However, this would involve a change of direction from the CJEU, so we do not discuss it further here.

123 For a discussion on the changing approach of the CJEU to human health protection derogations, as the EU legislature increasingly harmonised the fields of risk regulation in communicable diseases, see Tamara Hervey, 'The Role of the European Court of Justice in the Europeanization of Communicable Disease Control: Driver or Irrelevance?' (2012) 37 Journal Health Politics, Policy and Law 975-98.

124 E-commerce Directive (n 100) Art 3(4)(a)(i), (ii) and (iii). Case C-55/94 Gebhard EU:C:1995:411; Case C-275/92 Schindler EU:C:1994:119.

125 Directive 2005/36/EC (n 97).

126 As the CJEU put it in Case C-137/09 Josemans EU:C:2010:774, para 70: 'a restrictive measure can be considered to be suitable for securing the attainment of the objective pursued only if it genuinely reflects a concern to attain that objective in a consistent and systematic manner'. See, for instance, in the context of health services, Case C-490/09 Commission v Luxembourg (Laboratory Analyses) EU:C:2011:34; Case C-169/07 Hartlauer EU:C:2009:141, para 55; Cases C-171/07 and C-172/07 Apothekerkammer des Saarlandes and Others EU:C:2009:316, para 42; see Case C-333/14 Scotch Whisky Association and Others $v$ The Lord Advocate and The Advocate General for Scotland EU:C:2015:845; and in other contexts, such as gambling services, see e.g. Case C-42/07 Bwin International EU:C:2009:519, para 61; Case C-316/07 Stoß EU:C:2010:504, para 97; Case C 390/12 Pfleger EU:C:2014:281, paras 40-56. The CJEU adopts a strict scrutiny of public morality as an objective public interest justifying restrictions on free movement of services or goods, with particular care to decline to accept any double standards, see e.g. Case 121/85 Conegate EU:C:1986:114, concerning import of sex toys, and Cases 115\&116/81 Adoui and Cornuaille EU:C:1982:183 and Case C-268/99 Jany and Others EU:C:2001:616, concerning prostitution. 
recognised as inherent in the EU's legal order, and now found in the EU Charter of Fundamental Rights (CFR), ${ }^{127}$ is also required. ${ }^{128}$

What public policy is served by the current legal restrictions on abortion in Northern Ireland which might potentially justify a derogation from the principles of free movement in EU law? The abortion prohibitions contained in the 1861 Act have typically been seen as justified by two broad purposes: the promotion of public (women's) health and the protection of fetal life. ${ }^{129}$ With these broad purposes in mind, the former recognised separately by EU law, ${ }^{130}$ how might the UK argue that Northern Ireland's abortion laws satisfy EU law's requirements? The discussion below shows that this is not as easy as might be assumed, leaving scope to argue that Northern Irish law is importantly inconsistent with EU law.

First, if relying on the public health or consumer protection justification, the UK would have to show that Northern Irish law actually works to protect health and/or potential consumers of abortion services, or to prevent a risk of harm to (women's) health or to consumers. ${ }^{131}$ However, as described in some detail above, the abortion services offered by WoW and WHW are both safe and effective for the woman concerned. ${ }^{132}$

Mifepristone and misoprostol are prescription-only medicines. The CJEU's reasoning in DocMorris recognises the legitimacy of national controls on prescription-only medicines, arising from the greater risks of harm if misused than for non-prescription medicines, the consequent risks arising from false or forged prescriptions, the need to ensure that the medicines reach the correct person, and the need to secure efficient use of public money. ${ }^{133}$ The German ban on sale of prescription medicines through internet pharmacies was justified on these grounds. Surely a ban on internet-based provision of prescription-only abortion pills would be similarly justified?

We think not. The telemedical services offered by WoW and WHW must be distinguished from the services offered in DocMorris, with none of the successful arguments in DocMorris engaged. Under the EU's pharmaceuticals legislation, the decision of whether to authorise medicines as prescription-only on patient protection/ health grounds is a matter for the member state within which the medical professional who issues a prescription is established. Too great an interference with this principle (such as a total ban of a particular pharmaceutical being privately imported into a different member state,

127 The CFR enjoys 'the same legal value as the Treaties', Article 6(1) TEU.

128 See e.g. Case C-402/07 Sturgeon EU:C:2009:716; Case C-581/10 Nelson EU:C:2012:657. The human rights engaged in the circumstances we discuss include the right to life (EU CFR, Art 2), the right to human dignity (EU CFR, Art 1), the right to integrity of the person (EU CFR, Art 3), the right to respect for private and family life (EU CFR, Art 7), equality before the law (EU CFR, Art 20) and non-discrimination (EU CFR, Art 21). Other human rights which might be engaged include freedom from inhuman and degrading treatment (EU CFR, Art 3), right to liberty and security of the person (EU CFR, Art 6) and freedom to choose an occupation (EU CFR, Art 15).

129 See, generally, Sheldon (n 82).

130 Following the approach of EU law, we discuss each ground for derogation separately. We note that there is scope for further exploration of the ways in which the grounds interact, which might yield further insights about the disproportionality of the Northern Irish law.

131 The consumer here is the pregnant woman: it makes no sense, given the circumstances, to argue that the fetus is a service recipient in EU law. However, while the health of the fetus logically cannot be engaged in this context, see below for a discussion of public policy arguments foregrounding considerations of fetal life, nn 140-59 and accompanying text.

132 See above (nn 65-81).

133 Paras 117-23. 
where that pharmaceutical is authorised) would be a disproportionate infringement of the Treaty rules on free movement of goods, ${ }^{134}$ as well as freedom of establishment (of pharmacists, but also presumably of other medical professionals, including the doctors who prescribe medicines). The mutual recognition of professional qualifications, also secured by EU legislation, equally highlights the disproportionality of such an approach. It follows that compliance with domestic laws and the licensing of mifepristone and misoprostol in the countries in which the WoW and WHW doctors are professionally registered, and the authorisation of those medicines in Northern Ireland, precludes an absolute ban on cross-border mail-order trade on the grounds of protection of health.

Further, any negative health consequences of telemedical use of abortion pills need to be balanced against the health consequences of the alternative options available to a woman, as discussed above. ${ }^{135}$ There is overwhelming evidence to support the claim that restrictive abortion laws are very harmful to women's health, ${ }^{136}$ and there are thus good public health arguments to support the service that WoW and WHW provide. Indeed, as noted above, using pills to end an early pregnancy is far safer, not just than alternative (illegal) methods of ending that pregnancy, but it is also much safer for the woman concerned than continuing it. ${ }^{137}$ As was recognised in the Austrian courts, these services make a strong and positive contribution to the health and survival of women in countries where abortion is heavily restricted. ${ }^{138}$ This interpretation, to the effect that restricting Northern Irish women's access to the services offered by WoW and WHW is not a proportionate policy designed to achieve the objective of protecting health, is also consistent with human rights recognised in EU law. ${ }^{139}$

If there is a convincing justification for Northern Ireland's restrictive abortion policy, then, this must lie in a second broad concern: with the moral status of the fetus (a 'public policy' justification in EU law). The e-commerce Directive refers in particular to 'the prevention, investigation, detection and prosecution of criminal offences, including the protection of minors . . . and violations of human dignity concerning individual persons'.140 In making the assessment of whether such policies are proportionate, account must be taken of the action already taken by the other member state to protect that particular interest. ${ }^{141}$ So one might argue that, although domestic law in the Netherlands and Austria does not prioritise the protection of the fetus over the pregnant woman's interests in the same way as Northern Irish law does, there is no doubt that law in each jurisdiction does offer some protection to it (for example, in restricting access to abortion later in pregnancy).

134 See, analogously, involving private import of an over-the-counter medicine, Case C-215/87 Schumacher EU:C:1989:111.

135 See above (nn 37-45) and accompanying text.

136 Gilda Sedgh, Susheela Singh, Iqbal H Shah, Elisabeth Åhman, Stanley K Henshaw and Akinrinola Bankole, 'Induced Abortion: Incidence and Trends Worldwide from 1995 to 2008' (2012) 379 Lancet 625-32.

137 MBRRACE-UK (n 77); RCOG (n 63).

138 UVS (n 65).

139 Such as the right to human dignity (EU CFR, Art 1); right to integrity of the person (EU CFR, Art 3); right to respect for private and family life (EU CFR, Art 7); freedom from inhuman and degrading treatment (EU CFR, Art 3); and right to liberty and security of the person (EU CFR, Art 6). It is strongly arguable that the Northern Irish law itself breaches the dignity of the women whose right to choose what happens to their own bodies is compromised.

140 E-commerce Directive (n 100), Art 3(4)(i)(a).

141 Case C-76/90 Säger EU:C:1991:331. 
While many EU countries seek to deter abortion, however, the restrictiveness of the law in Northern Ireland marks it as a clear outlier, ${ }^{142}$ making it more difficult for the UK to demonstrate that the restrictions which it imposes offer a proportionate response compared to other available approaches. The repeated criticism of the extremely harsh criminal penalty and the refusal to provide abortion services even very early in pregnancy or in specific, limited circumstances (such as in the presence of a fatal fetal anomaly or where pregnancy results from a sexual assault) ${ }^{143}$ indicate the disproportionality of the Northern Irish position.

In the context of free movement of services under Article 56 TFEU, the CJEU has held that 'public policy' must be interpreted strictly. It may only be relied on if there is a 'genuine and sufficiently serious threat to a fundamental interest of society'. ${ }^{144}$ The CJEU has long recognised that protection of human rights may, in principle, constitute such a fundamental interest, which justifies a member state in derogating from the Treaty rules on freedom to provide services and free movement of goods. ${ }^{145}$ So if Northern Ireland's public policy seeks to protect the human rights of the fetus, ${ }^{146}$ it seems unarguable that this is a proportionate restriction, provided that there is no other way of achieving that aim which is less restrictive of free provision of services across national borders in the EU.

But this argument would require - very controversially - defending the position that a fetus is to be regarded as a holder of human rights in EU law. Such an interpretation would be fundamentally incompatible with current abortion law in almost every EU member state. Neither the CJEU ${ }^{147}$ nor the Council of Europe's ECtHR ${ }^{148}$ has decided to this effect in any context. To adopt this position is, in effect, to argue for a broad interpretation of the 'public policy' derogation, where the normal approach of the CJEU is to adopt a narrow interpretation. In our view, it is inconceivable that such an explicit position would be taken by the CJEU, given that the ECtHR has consistently rejected any attempt to recognise that a 'right to life' can be held by a fetus ${ }^{149}$ and that the EU CFR explicitly provides that the meaning and scope of EU CFR rights which correspond to ECHR rights is the same as those of ECHR rights, ${ }^{150}$ and interpretation of its other provisions is to be with due regard to inter alia the ECHR. ${ }^{151}$

However, the potential scope of a 'fundamental interest of society' is far broader than a concern with protecting human rights. Even if it is not accepted that the fetus can be a human rights holder, a member state might nonetheless assert a fundamental interest in the protection of fetal life. The issue of the moral status of the fetus in EU health law goes

142 Nebel and Hurka (n 29).

143 Committee on the Administration of Justice (n 10).

144 See e.g. Case C-54/99 Église de Scientologie EU:C:2000:124, para 17; Case C-36/02 Omega Spielhallen ECLI:EU:C:2004:614, para 30.

145 Case C-260/89 ERT EU:C:1991:254; Case C-275/92 Schindler EU:C:1994:119; Case C-36/02 Omega (n 144); Case C-341/05 Laval EU:C:2007:809; see also Case C-438/05 Viking EU:C:2007:772 on freedom of establishment.

146 The right to life of the unborn is not in itself a right in the EU CFR, although the right to life is. See further Elizabeth Wicks, 'Article 2 - Right to Life' in Peers et al (n 92).

147 See Case C-34/10, Brüstle v Greenpeace eV EU:C:2011:669; Case C-364/13 International Stem Cell Corporation v Comptroller General of Patents, Designs and Trade Marks EU:C:2014:2451.

$148 P$ and $S v$ Poland No 57375/08 (ECtHR 2012); A, B, C v Ireland [2010] ECHR 2032; Vo v France No 53924/00 (ECtHR 2004).

$149 V_{0}$ (n 148).

150 EU CFR, Art 52(3).

151 EU CFR, Preamble, and Explanations. For an extended discussion, see Jean-Paul Jacqué, 'The Explanations Relating to the Charter of Fundamental Rights of the European Union' in Peers et al (n 92). 
to the question of whether the life or health of the fetus justifies a restriction not only on trade, but also on the rights of the pregnant woman to dignity and autonomy, and the freedom of the WoW and WHW doctors to pursue a profession. The discretion enjoyed by a member state over public policy, expressed as a moral position, is constrained (through the legal doctrine of proportionality) by the impact of the exercise of that discretion over entitlements of individual women and health professionals to exercise not only trade rights, but also human rights, across EU borders. Taking an interpretation which saw protection extended to the fetus on moral grounds could constitute a breach of the woman's right to respect for private and family life, right to integrity of the person, right to liberty and security of the person, freedom from inhuman and degrading treatment, and human dignity. It may also breach the equality or non-discrimination provisions of the EU $\mathrm{CFR}$, as the restriction is on a medical service needed only by women, so discriminates on grounds of sex. ${ }^{152}$ Furthermore, in practice women who are less likely to be able to leave Northern Ireland to procure abortion services include women with disabilities that make it difficult for them to travel and women with less disposable income. Disability is an explicit ground for non-discrimination in the EU CFR. Although poverty is not, Article 21 EU CFR refers to property, birth and age as forbidden grounds and, more importantly, the list in Article $21 \mathrm{EU}$ CFR is not exhaustive. ${ }^{153}$ A wide interpretation of the public policy derogation, thus, potentially breaches equality or non-discrimination provisions in this regard too. The freedom to choose an occupation of the doctors in WoW and WHW is also potentially breached.

These observations take us into familiar territory of the 'balancing' of different interests using human rights frames. The 'public policy' derogation in EU law implies national discretion in reaching such a balance. ${ }^{154}$ If adopted here, that approach would favour the status quo. The 1861 Act's application in Northern Ireland would be respected through an interpretation of EU law which respects the rights articulated in the EU CFR, as understood through the lens of national 'margin of appreciation'. ${ }^{155}$ However, this would not necessarily be the approach of the CJEU. From the inception of its human rights jurisprudence, the CJEU has articulated human rights interpretation as a matter of EU law, ${ }^{156}$ not a matter entirely of deference to national settlements.

Taking the example of the 'right to human dignity', which is particularly pertinent to abortion, consider the Omega case, which concerned laser quest games. ${ }^{157}$ The CJEU on that occasion paid particular attention to the interpretation given by a particular member state (Germany) to the 'right to human dignity'. ${ }^{158}$ In order to be justified, it was not

152 See above (n 6).

153 It protects 'any ground such as ...'.

154 The European court with the longest pedigree of doing so is the ECtHR, Strasbourg. Without wanting to over-generalise, when it comes to balancing competing human rights claims, the ECtHR tends to respect the positions reached in legislative (or even policy) settlements in particular countries. See e.g. William A Schabas, The European Convention on Human Rights: A Commentary (Oxford University Press 2015); Bernadette Rainey, Elizabeth Wicks and Clare Ovey, Jacobs, White and Ovey: The European Convention on Human Rights (Oxford University Press 2014).

155 For a detailed recent discussion of the margin of appreciation as it operates in this specific context, see NIHRC's Application [2015] NIQB 96.

156 Case 29/69 Stauder v City of Ulm EU:C:1969:57; Case 4/7 Nold EU:C:1977:1; Case 11/70 Internationale Handelsgesellschaft EU:C:1970:114. Note, however, that the CJEU has - like all courts which decide 'constitutional issues' - also been attentive to the politics of its decisions, especially those involving human rights arguments, see e.g. the cases cited above (nn 84, 144, 145, 147).

157 Omega (n 144) paras 34, 37. See also Case C-124/97 Läärä EU:C:1999:435 and Case C-67/98 Zenatti EU:C:1999:514.

158 Omega (n 144) paras 37, 39, 40. 
necessary that the German approach corresponded to a common conception of human dignity, shared by all member states. Indeed, proportionality does not require consistency of approach across member states. There is scope, therefore, in EU law, for outlier positions on human rights interpretations. However, in Omega, as in other decisions concerning human rights, the CJEU explicitly asserts 'human dignity' as a principle of EU law. ${ }^{159}$ It does not apply the national conception of human dignity per se. So while the CJEU might respect the Northern Irish position as a human-rights-consistent derogation from free movement rules, this is far from certain.

Finally, we must consider the question of the consistency of policy within the boundaries of one member state. It is virtually impossible to see how existing Northern Irish law can be argued to be necessary and proportionate to protect public health or consumers when different rules apply elsewhere in the UK. We note that relevant English law (notwithstanding the medical exception to the 1861 Act carved out under the Abortion Act 1967) also potentially breaches EU law. A woman using the services of WoW or WHW to obtain pills that she could use at home in England to end an early pregnancy 160 would potentially be criminally liable under the Act, because her abortion would not have taken place in an NHS hospital or other approved premises or have been authorised by two doctors, as is required under s 1 of the Abortion Act 1967. In the unlikely event that such a woman were prosecuted, the UK would need to justify the place of provision and authorisation requirements of the Abortion Act, because, on their face, they constitute an unlawful breach of EU law on free movement of services, as they impede the practice of WoW and WHW doctors who are lawfully established and operating in full compliance with regulatory obligations in another member state. ${ }^{161}$ Simply arguing that high quality, safe abortion services are already offered free of change on the NHS would not constitute sufficient justification, as it is tantamount to an argument to the effect that the arrangements for lawful abortion services in other member states do not secure patient safety. Further, the Abortion Act has itself been criticised as imposing restrictions on the use of abortion pills that cannot be justified in terms of the best available standards of clinical practice. ${ }^{162}$ It would be difficult to show that such a prosecution (however unlikely to occur with regard to an abortion procured within the period of early pregnancy for which WoW and WHW offer services) would be proportionate to the restriction on women's receipt of abortion services and the freedom of WoW and WHW to supply services across borders. ${ }^{163}$

However, whether clinically grounded or not, domestic legal restrictions impact far less severely on women's access to abortion services in England, highlighting the disproportionate effect of the Northern Irish legal response to abortion and the far greater need for WoW and WHW's services within that jurisdiction. The very anomaly of the Northern Irish law, and its lack of attention to significant evolution in clinical practice, goes directly to the lack of credibility of the legal argument from proportionality. There can be nothing different about the proportionality test's balance in terms of public bealth or consumer protection based on whether the woman concerned is in

159 Omega (n 144) para 34. See further Weatherill (n 20); Koffeman (n 37).

160 WoW reports requests for abortion drugs from British women who are, for example, unable to leave the house without a chaperone or because of controlling, abusive partners. See Helen Rumbelow, 'The Woman Who Offers Abortions on the High Seas' The Times (2 Supplement, 22 October 2014).

161 The principle that restrictions on place of establishment/residence rules breach Art 56 TFEU is long established: see Case 33/74 Van Binsbergen EU:C:1974:131.

162 Sheldon (n 30).

163 There have, however, been rare prosecutions where women have used abortion pills to end a third trimester pregnancy, see e.g. R v Sarah Louise Catt (unreported 17 September 2012); R v Catt [2013] EWCA Crim 1187. 
England or Northern Ireland. If something is judged to be safe in England, it must also be judged to be safe in Northern Ireland. Unlike the protection of biodiversity arguments that justified a restriction on keeping of bees on the Danish island of Læsø, ${ }^{164}$ or the detailed and explicit public health data that justified different alcohol pricing in Scotland, ${ }^{165}$ there is nothing (other than the difference in approach to public policy) to suggest otherwise. It follows that maintaining a different conception of consumer protection or public health for only one part of the UK is highly unlikely to meet a proportionality test.

What about the public policy derogation? In general, the EU's legal structures - like those of all transnational trade agreements, which are agreements between states construct the 'society' within which 'fundamental interests' are to be protected as coterminous with the UK, the party to the relevant treaties. ${ }^{166}$ Nonetheless, in the early years of EU membership, public morality derogations (from free movement of pornography) were accepted where the legal expression of those morality standards differed between the different nations of the UK. ${ }^{167}$ In this regard, the CJEU accepts the internal national constitutional identities of the member states, and their constituent parts, when interpreting EU law. ${ }^{168}$ However, again this case can clearly be distinguished from that of telemedical abortion services. With regard to the free movement of pornography, the CJEU accepted that the UK policy as a whole was consistent (and hence justified) by reference to whether:

... [the relevant] laws, taken as a whole, have as their purpose the prohibition, or at least, the restraining, of the manufacture and marketing of publications or articles of an indecent or obscene character. In these circumstances it is permissible to conclude, on a comprehensive view, that there is no lawful trade in such goods in the United Kingdom. ${ }^{169}$

Because there was no lawful trade in such pornographic goods within the UK, it was permissible for the UK to prohibit their import from another member state. By contrast, with regard to abortion services, women in England, Wales and Scotland are able to access lawful domestic services using pills as, indeed, in very rare and highly restricted circumstances, are women in Northern Ireland. Further, DoH guidance explicitly envisages that a woman might travel to access such a service, with the only difference lying in the mode of supply of the service (whether the service itself or the patient crosses the border). Taking account of all of this, and the extent of policy inconsistency concerned, a mere divergence in views between Northern Ireland and the rest of the UK

164 Case C-67/97 Criminal Proceedings against Ditlev Blubme (the 'Danish bees case') EU:C:1998:584.

165 In the context of public health protection, there is a single recent example showing that it is possible to justify such measures, but only if detailed appropriate empirical data supports a different approach in just one part of a member state, see Case C-333/14 Scotch Whisky Association (n 126).

166 Note, though, that the EU is obliged to respect its member states' 'national identities, inherent in their fundamental structures, political and constitutional, inclusive of regional and local self-government' (Art 4(2) TEU): see $n 168$ below.

167 In Case 34/79 Henn and Darby EU:C:1979:295, the CJEU considered the laws of the different parts of the UK, namely England and Wales, Scotland, Northern Ireland and the Isle of Man, on pornography. These differ and derive from a variety of sources rather than from any coherent scheme.

168 Art 4(2) TEU. The CJEU has interpreted this provision, inter alia, in the context of different approaches to online gambling laws in the German Länder, see Case C-156/13 Digibet EU:C:2014:1756. However, online gambling should be distinguished from online abortion services, given the established safety of abortion pills, because the dangers to consumer and health protection from gambling are significantly contested, leaving greater national discretion to justify restrictive policies, see e.g. Stanleybet International and Others EU:C:2013:33, para 44.

169 Case 34/79 Henn and Darby (n 167) para 21. 
regarding how the moral status of the fetus should be recognised in law ${ }^{170}$ is insufficient to constitute a clear justification for the derogation from EU law. ${ }^{171}$

Recall also that the rules preventing access to lawful services are liable to impact primarily on those women who are unable (for example, because of their relative poverty, a disability, or caring commitments) to access abortion services in another country. In permitting women to access services by travelling to England or another country (and even facilitating this, by explicitly permitting the provision of advice regarding this option), Northern Irish law and policy is not only inconsistent but also discriminatory. If there is no objection to (wealthier, physically able) women travelling to receive abortion services, there can be no ethical justification on the grounds of the moral value of fetal life for objecting to the pills themselves 'travelling' (for less wealthy, less able women to use). In the circumstances we have investigated and with regard to the broad purposes which might be argued to support the restrictive Northern Irish law, there is no material difference between a Northern Irish woman who procures pills from WoW or WHW and a Northern Irish woman who obtains them following a consultation in, say, an English clinic and leaves immediately having taken them (other than that the latter risks managing a miscarriage on her journey home). To repeat: the only difference is in the 'mode' of supply of the service concerned. Can this really be sufficient to constitute a proportionate policy response? Add the significant international data demonstrating that restrictive laws do not actually end abortion and, indeed, the lack of data to show even that they reduce its incidence, ${ }^{172}$ and - in our view - the most convincing answer lies in the negative.

To recap: we have shown above that the doctor seeking to treat a patient with abortion pills is entitled, in principle, to rely on the rule in EU law of free movement and access to consumers/service recipients in other member states and that a woman facing an unwanted pregnancy is entitled to access the services thus offered. We have also set out the circumstances in which a state is entitled to derogate from these rules, describing the possibility of claiming an exception either on the basis of public health and consumer protection; or on the protection of a fundamental public policy interest (here, the protection of fetal life). The law discussed above is complex and we have shown that its application in this context raises a range of novel points. As such, the ultimate outcome of such a dispute is impossible to predict with certainty. However, what is vital is that the legal burden of establishing that a derogation from free movement rules can be justified lies on the member state concerned, and our analysis suggests numerous important hurdles that a state would struggle to overcome in making such a case. As such, we proceed on the basis that EU health law should be interpreted so as to give doctors and Northern Irish women rights to provide and receive the services provided by WoW and WHW across borders. We now explore some of the consequences of this conclusion for the law in Northern Ireland, outlining how the principles of EU law discussed above might be operationalised in practice.

170 We intend here both any divergence of views between Stormont and Westminster and between public opinion in Northern Ireland and the rest of the UK. As we noted above, public opinion in Northern Ireland appears to be far more liberal regarding abortion than is Stormont (n 12).

171 Indeed, the reunification of Germany resulted in a single abortion law for the whole of Germany, in part because of duties in EU law, see Spahn (n 83).

172 Abortion rates tend to be lower in sub-regions with liberal abortion laws: the lowest sub-regional rates of abortion (12 per 1000 women) are in Western Europe, where laws are least restrictive, and some of the highest sub-regional rates (29-39 per 1000) are in Latin America, where laws are generally very restrictive: Sedgh et al (n 136). 


\section{APPLICATION OF EU HEALTH LAW TO TELEMEDICAL ABORTION SERVICES IN NORTHERN IRELAND}

In general, although international treaties are binding, ${ }^{173}$ states are free to determine how they meet their international obligations. In a 'dualist' state like the UK, treaties do not automatically become part of domestic law. But the doctrine of 'consistent interpretation' means that there is a presumption of compliance with international obligations in the interpretation of subsequently adopted UK law. ${ }^{174}$ In the context of the EU Treaties (under the European Communities Act) ${ }^{175}$ and the ECHR (under the Human Rights Act), ${ }^{176}$ this obligation of consistent statutory interpretation extends also to previously enacted legislation. Future legislation implementing the UK's post-Brexit trade agreements with the EU will thus also be subject to the obligations in the Human Rights Act.

In addition, EU law has some qualities that international law, even international human rights law, does not share. In addition to the obligation of consistent interpretation, ${ }^{177}$ some provisions of EU law are 'directly effective' - that is to say, are potentially a source of rights enforceable by individuals within national courts, ${ }^{178}$ and of corresponding obligations. ${ }^{179}$ For example, from the very earliest cases, ${ }^{180}$ the direct effect of a provision of EU law has been available as a defence in criminal proceedings. Within the EU's sphere of competence, the 'supremacy' of EU law also requires national courts to apply EU law in priority over conflicting national law, which must be 'disapplied', irrespective of the date of enactment, or of normative or constitutional priority. ${ }^{181} \mathrm{EU}$ law requires 'an effective remedy' for everyone whose 'rights and freedoms' in EU law have been violated, ${ }^{182}$ even where the

173 Vienna Convention on the Law of Treaties 1969, Art 6.

174 The reasoning relies on the assumption that Parliament does not intend to put the UK in breach of its international obligations. Only clear and unambiguous statutory language, where consistent interpretation is not possible, should be interpreted inconsistently with such obligations. In general, the principle applies only to legislation adopted after a treaty has been ratified; EU law and the ECHR are in a special category. See e.g. Salomon v Commissioner of Customs and Excise [1976] 2 QB 116, per Diplock LJ, 143; Pan American World Airways $v$ Department of Trade [1976] 1 Lloyds Reports 257; Garland v British Rail Engineering [1983] 2 AC 751, per Lord Diplock, 771; R (Hirst) v London Northern District Coroner [2005] 1 AC 400, per Lord Brown, 415-16; R v Secretary of State for the Home Department exp Brind [1991] 1 AC 696; Judicial Committee of the Privy Council in Procurator Fiscal v Brown [2001] SLT 59, per Lord Reid, [65]. See further, James Crawford, Brownlie's Principles of Public International Law (Oxford University Press 2012) 63-6; Anthony W Bradley, Keith D Ewing, Christopher J S Knight, Constitutional and Administrative Law (Pearson 2014); André Nollkaemper, National Courts and the International Rule of Law (Oxford University Press 2011) 139-65; Helmut P Aust and Georg Nolte (eds), The Interpretation of International Law by Domestic Courts: Uniformity, Diversity, Convergence (Oxford University Press 2016).

175 European Communities Act 1972, s 2(4), which provides 'any enactment . . to be passed shall be construed and have effect' (italics added) subject to the remainder of s 2, which includes the doctrines of supremacy and direct effect of EU law: Pickstone v Freemans [1989] AC 66; Litster v Forth Dry Dock [1990] 1 AC 546.

176 Human Rights Act 1998, s 3, which 'applies to primary legislation and subordinate legislation whenever enacted' provides 'so far as it is possible to do so, primary legislation and subordinate legislation must be read and given effect in a way which is compatible with the Convention rights'; Ghaidan v Godin-Mendoza [2004] UKHL 30; $\mathrm{R} v$ Secretary of State for the Home Department ex parte Brind (n 174).

177 Case C-106/89 Marleasing EU:C:1990:395.

178 National courts are obliged to comply with EU law, see Art 4(3) TEU. In general, if a state adopts a 'monist' approach to ordinary international law, all international law is 'directly effective' in its legal system.

179 Case 26/62 Van Gend en Loos EU:C:1963:1.

180 Case 148/78 Pubblico Ministero v Ratti EU:C:1979:110.

181 Case C-617/10 Akerberg Fransson EU:C:2013:105; Case 106/77 Simmenthal EU:C:1978:49; Case 6-64 Costa v ENEL EU:C:1964:66.

182 EU CFR, Art 47; see e.g. Case C-177/88 Dekker EU:C:1990:383; Case C-430\&431/93 Van Schijndel EU:C:1995:441; Case C-213/89 Factortame EU:C:1990:257; Case C-6\&9/90 Francovich EU:C:1991:428. 
violation is by national courts. ${ }^{183}$ These qualities of EU law are politically controversial particularly at the current time, when the shape of future relations between the UK and EU is under discussion - but they have been accepted by courts in all the member states, including the UK. ${ }^{184}$

It follows, firstly, that the Offences Against the Person Act 1861 must be interpreted in accordance with these doctrines. In the case of EU law, if a consistent interpretation is impossible, the Act must be 'disapplied', logically leaving the matter to be settled under the common law. As we explained above, the 1861 Act is currently interpreted in such a way that 'procurement of miscarriage' is not considered 'unlawful', and thereby criminally prohibited, where it is performed for the purpose of 'preserving the life of the mother'. ${ }^{185}$ This exception, carved out by Bourne, which justifies the provision of abortion services on the grounds of a patient's mental and physical health, has historically been subject to a very narrow interpretation within Northern Ireland. However, Bourne offers a notoriously vague test and one which rests heavily on the good faith view of the doctor, allowing considerable scope for clinical discretion. ${ }^{186}$ If interpreted consistently with the EU law rights of the doctor to supply cross-border services, and with due respect to that doctor's clinical judgement, recognised as equivalent to that of a doctor established and lawfully providing medical services in Northern Ireland, this opens the possibility for establishing an exception to criminal prosecution under the 1861 Act. In short, a doctor established in another EU member state, must be accorded the same freedom as a doctor based within Northern Ireland to reach a clinical judgement to the effect that an abortion is necessary to avoid a serious adverse effect on the woman's health and, accordingly, to offer appropriate treatment.

While there are few facts in the public domain regarding the case of the Northern Irish mother facing prosecution, it seems highly plausible that such a good faith medical opinion might have been reached in the case of her daughter, a minor seeking abortion. Furthermore, once it has been decided that the doctor has acted lawfully, within the exception carved out by Bourne, then logically neither can the woman being treated by that doctor have committed a criminal act, given that there has been no 'unlawful' miscarriage within the terms of the 1861 Act. Moreover, any attempted prosecution of others involved in supply or procurement of the pills (such as the mother) would also fail to meet the requirement for prosecution under s 59 that the pills were to be 'unlawfully used or employed'. Neither the doctor, nor the woman using the abortion pills, nor indeed anyone who had helped her to do so, would have committed a criminal offence. In this way, both the doctor's and the woman's rights in EU law are granted 'effective judicial protection' through the doctrine of consistent interpretation. Where this nondiscriminatory treatment is not secured, either the doctor or a woman could challenge any criminal prosecution on the grounds that it infringes EU law as an unjustified restriction on her freedom to provide, or to access, cross-border services. Any attempt on the part of the Northern Irish authorities to justify prosecution would need to satisfy the requirements of EU law and we have argued above that they would face important hurdles in their struggle to do so.

A post-Brexit agreement liberalising trade in services, when implemented into UK law, will need to be interpreted consistently, if possible, with human rights obligations in the

183 Case C-224/01 Köbler EU:C:2003:513.

184 Factortame v Secretary of State for Transport [1991] 1 AC 603.

185 Bourne (n 31).

186 See above (n 32). 
Human Rights Act. Equally, it must be at least arguable that, in the future, if the agreement gives rights to receive and provide cross-border medical services, Bourne should be interpreted consistently with both the trade agreement's implementing legislation and the Human Rights Act.

Secondly, it also follows from the doctrine of consistent interpretation that any official guidance on abortion issued by the Northern Irish government should reflect transnational norms in its interpretation of the applicable domestic law. Current DoH guidance is flawed in failing to do so, in that it seeks to establish a more restrictive reading of the Bourne judgment than is consistent with the UK's human-rights-consistent obligations in EU law. ${ }^{187}$ Its sweeping judgement that 'there is no effective medical supervision' of pills sourced from websites is flawed in failing to recognise that some of these pills are offered on prescription from doctors lawfully established elsewhere in the EU, following an online or telephone consultation, with follow-up care and advice available for as long as the woman needs it. ${ }^{188}$ It thus breaches EU law proportionality principles in that it fails to take into account the differences between the services such doctors provide and the undoubted dangers of procuring pills online from unscrupulous providers. Indeed, if the concern is truly with the danger that vulnerable women might suffer at the hands of the latter, then this might more usefully be translated into a prompt for official guidance that allows women to identify safe, reputable suppliers, and facilitates the provision of accurate information regarding correct use of abortion pills and when to seek further care. ${ }^{189}$ A complainant who can establish locus standi might thus seek to rely on EU law to bring a judicial review action, arguing that the DoH guidance is an unjustified policy response in that it fails to express adequately the applicable law.

Finally, EU law might be invoked, again through judicial review, should the necessary locus and admissibility rules be satisfied, to challenge any attempt by the Northern Irish authorities to prevent the physical importation of abortion pills. Given the 'bundling' of the provision of the medical service with the provision of the pills, such an act on the part of customs authorities would be a prima facie (and, we argue, unlikely to be justified) restriction on freedom to provide and receive services in EU law. ${ }^{190}$

\section{Conclusions}

The conviction of a young woman for unlawful procurement of miscarriage and the ongoing prosecution of a mother who had sought to support a pregnant teenage daughter faced with Northern Ireland's highly restrictive prohibitions on abortion each highlight a law that is poorly aligned not just with human rights norms, ${ }^{191}$ but also - as we have

187 DHSSPS (n 35).

188 Ibid para 6.6.

189 For a justification of a harm reduction strategy in this context, see further Joanna Erdman, 'Access to Information on Safe Abortion: A Harm Reduction and Human Rights Approach' (2011) 34 Harvard Journal Law and Gender 413; Sheldon (n 18).

190 It would also be an infringement of EU law on free movement of goods, were it not for the fact that the pills are shipped directly from India, a non-EU state. Regulation 2015/478/EU on common rules for imports OJ 2015 L 83/16, which implements the EU's common commercial policy, provides that it 'shall not preclude the adoption by Member States of prohibitions . . . on grounds of public morality, public policy . . protection of health ...' (Art 24, italics added). The provision is subject to a requirement to inform the Commission of the relevant measures. Furthermore, interpretation of that provision (or rather its legislative predecessor Regulation 3285/94/EC OJ 1994 L 349/53 on the common rules for imports), along with EU rules on customs duties, gives significant margin of discretion to member states. Unlike in the internal free movement of goods context, where a strict proportionality principle applies, the CJEU has adopted a more lenient approach to application of proportionality, see Case C-394/97 Heinonen EU:C:1999:308, paras 39-44.

191 See above (nn 6-10). 
demonstrated above - principles of EU law, and transnational trade law more generally. The women involved in each case could have accessed lawful termination services by leaving Northern Ireland, resulting in treatment with exactly the same safe and effective medicines. If they had done so, EU and ECHR law would have protected their rights to obtain information regarding services offered in another member state and to travel to make use of them. However, travelling for abortion care imposes a heavy burden on women and is particularly difficult or simply impossible for some, including for reasons of disability, age, or poverty.

In this article, we have discussed the case where abortion services travel to women, focusing on the work of two not-for-profit groups, WoW and WHW. While the principles of EU law involved are complex, contested and raise many novel issues for resolution, we suggested that they nonetheless raise important and hitherto unexplored legal arguments. Notably, they are significant in the interpretation of Bourne, with implications for individual prosecutions; they suggest the need for revision of existing official guidance for health and social care professionals on abortion services in Northern Ireland; and they might potentially be invoked to challenge any attempt to interrupt the supply of abortion pills across borders. More generally, legal challenges brought on the basis of EU law can sometimes offer broader opportunities for litigation as a political strategy, highlighting the extent to which domestic law is out of step with contemporary European norms and clinical developments, and contributing pressure for domestic legal reform. ${ }^{192}$

There is no doubt that using EU law in an attempt to defend or extend reproductive rights in Northern Ireland would be highly controversial and, considering the failure of even very moderate attempts to reform abortion law to date, that it would meet significant political resistance. Contestation regarding the application and effect of EU law is always acute in those cases where deeply entrenched social or moral values differ across the EU.193 We are acutely aware that, in a context of ongoing heightened controversy regarding Brexit and the current perilous state of the Northern Irish peace process, ${ }^{194}$ any attempt to assert EU principles as a basis for disrupting domestic legal provisions on an issue as deeply contested as abortion is particularly fraught with danger. While these risks are real, however, appreciation of them should not detract from an awareness of the ongoing, severe suffering caused to women by existing abortion laws and the consistent refusal of both Stormont and Westminster to respond to it, notwithstanding the repeated condemnations from human rights bodies noted above and the UK government's own recognition of safe, legal abortion as a basic human right in other contexts. ${ }^{195}$ If the equal rights apparently promised to Northern Irish women in the

192 By the time that the litigation in Human Fertilisation and Embryology Authority, ex parte Blood [1997] 2 All ER 687 was concluded, the relevant English law had already been changed so as to prevent a similar situation arising in the future. See further Hervey (n 107); Morgan and Lee (n 107). In an older case, the European Parliament condemned the practice of subjecting West-German women to involuntary gynaecological examinations with a view to prosecution for extraterritorial abortion, inter alia, on the basis that the internal borders of the European Community may not be used to threaten citizens with prosecution for activities . . legal in some states but not in others': see Resolution on Compulsory Gynaecological Examination at Dutch/German Border of 14 March 1991, OJ 1991 C106/13; German law was changed. See further Spahn (n 83).

193 See the case law cited above (nn 84, 126, 144, 147, 167, 168); Weatherill (n 20); Koffemann (n 27).

194 Henry McDonald, 'Martin McGuinness Resigns as Deputy First Minister of Northern Ireland' The Guardian (10 January 2017) <www.theguardian.com/politics/2017/jan/09/martin-mcguinness-to-resign-as-northernireland-deputy-first-minister>.

195 DFID (n 13). 
Belfast Agreement are still to be achieved some 20 years on, ${ }^{196}$ then it is time to pursue those rights elsewhere.

We noted above a long-standing debate about whether the EU and its law are good for women. ${ }^{197}$ This has, in part, reflected broader concerns regarding both the balance between the EU's economic and social agendas 198 and the extent to which supposedly remote, unelected European elites have developed and imposed laws and policies that are unreflective of local needs and values. ${ }^{199} \mathrm{EU}$ health law and policy has here been criticised specifically for its harmful impact on the social settlements expressed in national health systems, including the potential undermining of a financial sustainability grounded in limiting access to medical treatment through gatekeeper medical professionals. ${ }^{200}$ In that discussion, individual rights claims under EU law are characterised as those of consumers or providers of services operating within markets and asserting individual interests which ignore, or are actively harmful to, social solidarity. ${ }^{201}$ Similar debates arise from the proposed application of trade agreements, such as TTIP, to medical services.

Without wanting to over-claim from the specifics of the rather different case we have considered above, we take the view that further reflection on whose solidarity is invoked and on what terms it has been achieved is worthwhile. The law of the internal market itself expresses European notions of social and moral values that are irreducible to mere economic rights. Far from acting as self-serving, individualist economic actors in the EU's market, the women at the heart of our analysis are asserting not merely trade-based principles of free movement of services, but also rights to human dignity, bodily integrity, liberty and security, private and family life, and equality and non-discrimination. The work of WoW and WHW is profoundly and explicitly grounded in a concern for social justice and in an ethic of solidarity with the women they serve, which cut across national boundaries. Our analysis suggests that, at least in this one specific case, the EU might offer important support for broad social solidarities, providing additional opportunities for contestation where other legal arguments have been unsuccessful. In this instance, transnational trade law may have the potential to facilitate - rather than to limit - the promotion of women's reproductive health, social equality and citizenship rights.

196 Horgan and O'Connor (n 14).

197 See above (n 21).

198 See Fritz Scharpf, 'The Asymmetry of European Integration, or Why the EU cannot be a "Social Market Economy" 8 Socio-Economic Review (2010) 211; Michael Dougan and Eleanor Spaventa, Social Welfare and EU Law (Hart 2005); Jo Shaw (ed), Social Law and Policy in an Evolving EU (Hart 2000); Ruth Nielsen and Erika Szyszczak, The Social Dimension of the European Union (Copenhagen Business School Press 1997).

199 For an overview of the significant literature here, see Stijn Smismans, 'Democracy and Legitimacy in the European Union' in Michelle Cini and Nievez Pérez-Solórzano Borrogán (eds), European Union Politics (Oxford University Press 2016).

200 For an extended discussion, see Hervey and McHale (n 93) 211-91.

201 On the concept of solidarity, see Peter Baldwin, The Politics of Social Solidarity (Cambridge University Press 1992); Steinar Stjernø, Solidarity in Europe: The History of an Idea (Cambridge University Press 2009); Barbara Prainsack and Alena Buyx, Solidarity: Reflections on an Emerging Concept in Bioethics (Nuffield Council on Bioethics 2011). 
